\title{
Optimal estimation of the surface fluxes of methyl chloride using a 3-D global chemical transport model
}

\author{
X. Xiao ${ }^{1, *}$, R. G. Prinn ${ }^{1}$, P. J. Fraser ${ }^{2}$, P. G. Simmonds ${ }^{3}$, R. F. Weiss ${ }^{4}$, S. O'Doherty ${ }^{3}$, B. R. Miller ${ }^{4}$, P. K. Salameh ${ }^{4}$, \\ C. M. Harth ${ }^{4}$, P. B. Krummel ${ }^{2}$, L. W. Porter ${ }^{5,}$, J. Mühle ${ }^{4}$, B. R. Greally ${ }^{3}$, D. Cunnold ${ }^{6, \dagger}$, R. Wang ${ }^{6}$, S. A. Montzka ${ }^{7}$, \\ J. W. Elkins ${ }^{7}$, G. S. Dutton ${ }^{7}$, T. M. Thompson ${ }^{7}$, J. H. Butler ${ }^{7}$, B. D. Hall ${ }^{7}$, S. Reimann ${ }^{8}$, M. K. Vollmer ${ }^{8}$, F. Stordal ${ }^{9}$, \\ C. Lunder ${ }^{9}$, M. Maione ${ }^{10}$, J. Arduini ${ }^{10}$, and Y. Yokouchi ${ }^{11}$ \\ ${ }^{1}$ Department of Earth, Atmospheric, and Planetary Sciences, MIT, Cambridge, MA 02139, USA \\ ${ }^{2}$ Center for Australian Weather and Climate Research, CSIRO Marine and Atmospheric Research, Aspendale, Victoria, 3195 , \\ Australia \\ ${ }^{3}$ School of Chemistry, University of Bristol, Bristol, UK \\ ${ }^{4}$ Scripps Institution of Oceanography, University of California, San Diego, La Jolla, CA 92093, USA \\ ${ }^{5}$ Center for Australian Weather and Climate Research, Bureau of Meteorology, Melbourne, Victoria, 3000, Australia \\ ${ }^{6}$ Georgia Institute of Technology, Atlanta, GA, USA \\ ${ }^{7}$ ESRL, NOAA, Boulder, CO, USA \\ ${ }^{8}$ Swiss Federal Institute for Materials Science and Technology, Laboratory for Air Pollution/Environmental Technology, \\ Duebendorf, Switzerland \\ ${ }^{9}$ Norwegian Institute for Air Research, Kjeller, Norway \\ ${ }^{10}$ University of Urbino, Urbino, Le Marche, 61029, Italy \\ ${ }^{11}$ National Institute for Environmental Studies, Tsukuba, Ibaraki, Japan \\ *now at: Civil \& Environmental Engineering, Rice University, Houston, TX 77005, USA \\ $\dagger$ deceased
}

Received: 28 September 2009 - Published in Atmos. Chem. Phys. Discuss.: 23 December 2009

Revised: 3 June 2010 - Accepted: 4 June 2010 - Published: 22 June 2010

\begin{abstract}
Methyl chloride $\left(\mathrm{CH}_{3} \mathrm{Cl}\right)$ is a chlorine-containing trace gas in the atmosphere contributing significantly to stratospheric ozone depletion. Large uncertainties in estimates of its source and sink magnitudes and temporal and spatial variations currently exist. GEIA inventories and other bottom-up emission estimates are used to construct a priori maps of the surface fluxes of $\mathrm{CH}_{3} \mathrm{Cl}$. The Model of Atmospheric Transport and Chemistry (MATCH), driven by NCEP interannually varying meteorological data, is then used to simulate $\mathrm{CH}_{3} \mathrm{Cl}$ mole fractions and quantify the time series of sensitivities of the mole fractions at each measurement site to the surface fluxes of various regional and global sources and sinks. We then implement the Kalman filter (with the unit pulse response method) to estimate the surface fluxes on regional/global scales with monthly resolution from Jan-
\end{abstract}

Correspondence to: X. Xiao

(xue.xiao@rice.edu) uary 2000 to December 2004. High frequency observations from the AGAGE, SOGE, NIES, and NOAA/ESRL HATS in situ networks and low frequency observations from the NOAA/ESRL HATS flask network are used to constrain the source and sink magnitudes. The inversion results indicate global total emissions around $4100 \pm 470 \mathrm{Gg} \mathrm{yr}^{-1}$ with very large emissions of $2200 \pm 390 \mathrm{Gg} \mathrm{yr}^{-1}$ from tropical plants, which turn out to be the largest single source in the $\mathrm{CH}_{3} \mathrm{Cl}$ budget. Relative to their a priori annual estimates, the inversion increases global annual fungal and tropical emissions, and reduces the global oceanic source. The inversion implies greater seasonal and interannual oscillations of the natural sources and sink of $\mathrm{CH}_{3} \mathrm{Cl}$ compared to the a priori. The inversion also reflects the strong effects of the 2002/2003 globally widespread heat waves and droughts on global emissions from tropical plants, biomass burning and salt marshes, and on the soil sink.

Published by Copernicus Publications on behalf of the European Geosciences Union. 


\section{Introduction}

Methyl chloride $\left(\mathrm{CH}_{3} \mathrm{Cl}\right)$ is the largest, natural source of stratospheric chlorine, contributing $15-16 \%$ of current stratospheric chlorine content (Montzka and Fraser, 2003; Clerbaux and Cunnold, 2006). Methyl chloride is expected to play an increasing role in determining future levels of stratospheric chlorine as the impact of the anthropogenic Montreal Protocol species declines. The mean mole fraction of $\mathrm{CH}_{3} \mathrm{Cl}$ in the remote troposphere is typically $550 \mathrm{ppt}$ (Yokouchi et al., 2000, 2002; Cox et al., 2003; Simmonds et al., 2004). Measurements also show latitudinal variations in $\mathrm{CH}_{3} \mathrm{Cl}$ concentrations, specifically with higher values in the tropics than at the poles (570 vs. 500 ppt, Yokouchi et al., 2000), presumably caused by large tropical terrestrial sources. Khalil and Rasmussen (1999) reported a northern tropical seasonal cycle with an amplitude of about 10\%, while Cox et al. (2003) found a clear but much smaller annual cycle at Cape Grim with an amplitude of $25 \mathrm{ppt}(5 \%)$, explicable mainly in terms of seasonal changes in the abundance of the hydroxyl $(\mathrm{OH})$ radical, which is the dominant sink of $\mathrm{CH}_{3} \mathrm{Cl}$ in the troposphere.

Mole fractions for $\mathrm{CH}_{3} \mathrm{Cl}$ in firn air from Antarctica dating back to the early 1900 s were only $5-10 \%$ lower than the present day (Butler et al., 1999), which is consistent with predominantly natural emissions. Trudinger et al. (2004) also reconstructed $\mathrm{CH}_{3} \mathrm{Cl}$ levels back to before 1940 from firn data, and associated its evolution mostly with the biomass burning source. Recent research has focused on identifying and quantifying $\mathrm{CH}_{3} \mathrm{Cl}$ natural sources and sinks (e.g., Cox et al., 2004), including newly identified sources from tropical plants (Yokouchi et al., 2002). Keppler et al. (2005) used stable carbon isotope ratios to study and quantify $\mathrm{CH}_{3} \mathrm{Cl}$ formation from abiotic methylation of chloride, which exists ubiquitously in terrestrial ecosystems and results in more $\mathrm{CH}_{3} \mathrm{Cl}$ emissions from tropical plants during hot periods (Hamilton et al., 2003). The anthropogenic sources (coal combustion, incineration, and industrial processes) were quantified in the Reactive Chlorine Emissions Inventory (RCEI) (McCulloch et al., 1999) and sum to $160 \mathrm{Gg} \mathrm{yr}^{-1}\left(1 \mathrm{Gg}=10^{9} \mathrm{~g}\right)$, which is only about $5.4 \%$ of the total estimated sources. The oceans were once thought to be the dominant source of $\mathrm{CH}_{3} \mathrm{Cl}$ until the net flux was revised sharply downward in 1996 by Moore et al. (1996). Current oceanic flux estimates account for $20 \%$ of the total. Yokouchi et al. (2002) later suggested that $\mathrm{CH}_{3} \mathrm{Cl}$ emissions from tropical plants might be the largest known source. They determined that a specific group of ferns and trees in Southeast Asia alone produce $910 \mathrm{Gg} \mathrm{yr}^{-1}$, using the average emission rate from three species of Dipterocarpaceae and the leaf biomass reported for mature tropical lowland rainforest. Considering the large variability of $\mathrm{CH}_{3} \mathrm{Cl}$ emissions among species of a family and among individual plants of a species, this estimate is expected to have a very large uncertainty. Moreover, only contributions from Dipterocarpaceae in Southeast Asia were listed in this inventory. Little is known about $\mathrm{CH}_{3} \mathrm{Cl}$ emissions from Dipterocarpaceae elsewhere in the world, as well as from other $\mathrm{CH}_{3} \mathrm{Cl}$-emitting tropical plants. This global vegetation source certainly warrants additional investigation which is one of the main goals of this paper.

Reaction with the $\mathrm{OH}$ radical is the dominant pathway for removal of $\mathrm{CH}_{3} \mathrm{Cl}$ from the atmosphere, resulting in an $\mathrm{OH}-$ removal "process" lifetime of 1.5 years (a "process" lifetime is defined as the total atmospheric content divided by the rate of removal by that process) (Montzka and Fraser, 2003). Other minor loss processes include reaction with chlorine radicals in the marine boundary layer (13-year lifetime), microbially mediated uptake by soils (28-year lifetime), and uptake in polar oceans (70-year lifetime). These processes in total result in an atmospheric lifetime of 1.3 years (Montzka and Fraser, 2003), while the latest scientific assessment on ozone depletion stated that the atmospheric lifetime of $\mathrm{CH}_{3} \mathrm{Cl}$ is 1.0 years based on a revised loss rate (Clerbaux and Cunnold, 2006). The current best estimate of the magnitude of the identified $\mathrm{CH}_{3} \mathrm{Cl}$ sources is about $25 \%$ less than the best estimate of the magnitude of the better quantified known sinks (Cox et al., 2003). This suggests that there are still missing and/or underestimated $\mathrm{CH}_{3} \mathrm{Cl}$ sources. Moreover, due to the complicated natural behavior of the known sources, significant uncertainties exist in their magnitudes and in their variations due to seasonal and climatic changes. Using a 3-D global model of atmospheric $\mathrm{CH}_{3} \mathrm{Cl}$, Lee-Taylor et al. (2001) were able to reproduce the observations of Khalil and Rasmussen (1999) by using a massive tropical terrestrial source of $\sim 2380 \mathrm{Gg} \mathrm{yr}^{-1}$ and reducing previous estimates of emissions from Southeast Asia. Yoshida et al. (2006) used a Bayesian least squares inverse method in a 3-D model to constrain hemispheric and seasonal biogenic and biomass burning sources with 3-month resolution. Although the available measurements covered several years, an "average year" was generated for both the measurements and the derived sources. The estimated biogenic, biomass-burning, and oceanic sources were 2500 (close to the Lee-Taylor et al. (2001) estimate), 545, and 761 (double the bottom-up estimate) $\mathrm{Gg} \mathrm{yr}^{-1}$, respectively. However, actual month-to-month and interannual variability in these sources related to climatic changes was not resolved by this approach.

To assess the interannual variability as well as seasonal changes in the surface fluxes of $\mathrm{CH}_{3} \mathrm{Cl}$, we use the inverse modeling approach to optimally deduce the magnitudes of the surface fluxes of $\mathrm{CH}_{3} \mathrm{Cl}$ from chosen regions and processes between 2000 and 2004 at monthly time resolution. In particular, we adapt the Kalman filter for estimating timevarying sources and apply it in a 3-D chemical transport model by using the $\mathrm{CH}_{3} \mathrm{Cl}$ surface observations from multiple measuring networks. 


\section{Observations}

The accuracy of the inverse modeling is highly dependent on the availability, accuracy and precision of the measurements. We use both high frequency in situ and low frequency flask observations of the mole fractions of $\mathrm{CH}_{3} \mathrm{Cl}$. These two sampling strategies represent two complementary approaches to global sampling: high sampling frequency (in situ) and high spatial coverage (flasks). High frequency in situ $\mathrm{CH}_{3} \mathrm{Cl}$ measurements are available from: the Advanced Global Atmospheric Gases Experiment (AGAGE) (Prinn et al., 2000); the System for Observation of Halogenated Greenhouse Gases in Europe (SOGE) and the National Institute for Environmental Studies (NIES) in Japan, which are both affiliated with AGAGE; and the Halocarbons and other Atmospheric Trace Species (HATS) In Situ Monitoring Program of NOAA/ESRL (http://www.esrl.noaa.gov/gmd/hats/insitu/ cats/). Low frequency observations are available from the HATS Flask Sampling Program at NOAA/ESRL (Montzka et al., 1999, 2000) and from NIES. Figure 1 shows the locations of the observing sites used in this study, and additional information is listed in Table 1. We used observations from January 2000 to November 2005 from these networks (where available) in order to estimate the monthly surface fluxes during 2000-2004. In this time frame, AGAGE data were from two instruments, the ADS GC-MS (gas chromatographmass spectrometer with an adsorption-desorption system) for 2000-2004 and the Medusa GC-MS for 2005; the two instruments were intercompared (and agreed well), and used the same calibration scale. We used high frequency data with obvious pollution events removed but the difference between removing and not removing these events is important only at MHD and CGO. At the remote sites the difference is negligible (e.g., monthly means with pollution are on average only $0.19 \%$ larger than without pollution at JUN; this is much less than the overall observational errors discussed later).

The networks listed in Table 1 are using different calibration scales. The AGAGE and SOGE networks use the AGAGE Scripps Institution of Oceanography 2005 (SIO05) $\mathrm{CH}_{3} \mathrm{Cl}$ scale. Regular comparisons of data between AGAGE/SOGE and the other networks provide estimates of the ratios of the scales used by the other laboratories to the SIO-05 scale (Krummel et al., 2009) as shown in Table 1. While an objective assessment of the errors in these internetwork ratios is not available, we have tested the sensitivity of our inversions to errors in these ratios by repeating the inversions assuming that the percentage differences in mole fractions between AGAGE and each of the other networks are a significant factor of 1.5 (i.e., 50\%) larger than the Krummel et al. (2009) values (see Table 1 for adjusted ratios and Sect. 5.3 for discussion of the results of the inversions using these adjusted ratios). We note that the actual differences between the networks are only 0.6 to $2 \%$ for $\mathrm{CH}_{3} \mathrm{Cl}$.

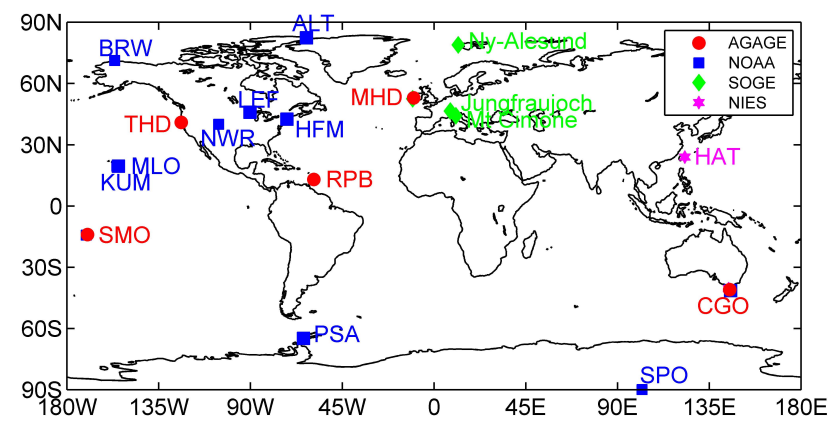

Fig. 1. Location of $\mathrm{CH}_{3} \mathrm{Cl}$ observing sites from different surface networks.

Our inverse methods use monthly mean mixing ratios $(\chi)$ and estimates of their uncertainties $(\sigma)$. The $\chi$ values of the high frequency data are directly computed from the measurements made in each month at each site. For the low frequency flask measurements, only a few (weekly or bi-weekly) measurements are taken in each month. Although $\chi$ values are also calculated from the available sparse flask data, larger uncertainties are assigned to these flask means as described below. The variances $\left(\sigma^{2}\right)$ of the monthly means for both in situ and flask data are estimated as the sum of the variances from: (1) the measurement error; (2) the error associated with the frequency of sampling used to define the monthly mean; and (3) the "mismatch" or "representation" error associated with equating the local point observations with the model grid volume average (Chen and Prinn, 2006). This assumes reasonably that these errors are uncorrelated. The measurement error includes those associated with instrumental, sampling, and inter-calibration imperfections. The instrumental precision varies slightly between different laboratories. The sampling frequency error accounts for how well the observational monthly mean is defined given a finite number of measurements; the flask data have larger errors of this kind due to their low sampling frequency. The "mismatch" or "representation" error may either be considered a model error due to the failure of the model to represent a point measurement, or an observational error due the failure of a point measurement to represent the model volume average. For implementation purposes in the Kalman filter we choose to put the uncertainty associated with mismatch into the total observational errors. The standard deviations of the high frequency in situ measurements provide reasonable estimates of the mismatch errors, because during each month the site samples a substantial fraction of the air mass from the large volume of air in the grid cell box containing that site (Prinn, 2000). For the flask measurements, since only weekly or bi-weekly air masses are sampled, we estimate the mismatch error at each site using the standard deviation of the modeled mole fractions $(y)$ at the nine grid cells surrounding and containing the site (Chen and Prinn, 2006). Note that this standard deviation is therefore dependent on the site location and time. 
Table 1. Location of the $\mathrm{CH}_{3} \mathrm{Cl}$ measuring sites and their assumed calibration factors $(\mathrm{CF})$ relative to the $\mathrm{SIO}-05 \mathrm{CH}_{3} \mathrm{Cl}$ scale used by the AGAGE network. Data at each site were divided by the listed calibration factor in order to combine them under a common scale. Calibration factors in parentheses are used in a sensitivity exercise and are calculated by multiplying the interlaboratory differences (CF-1) by 1.5 (i.e., increasing the differences by $50 \%$ ).

\begin{tabular}{|c|c|c|c|c|c|c|c|}
\hline Number & ID & Location & Latitude & Longitude & Altitude & Network & Calibration factor (CF) \\
\hline \multicolumn{8}{|c|}{ High Frequency Observations } \\
\hline 1 & MHD & Mace Head, Ireland & $53.3^{\circ} \mathrm{N}$ & $9.9^{\circ} \mathrm{W}$ & 25 & AGAGE/SOGE & 1 \\
\hline 2 & THD & Trinidad Head, California & $41.0^{\circ} \mathrm{N}$ & $124.0^{\circ} \mathrm{W}$ & 140 & AGAGE & 1 \\
\hline 3 & RPB & Ragged Point, Barbados & $13.0^{\circ} \mathrm{N}$ & $59.0^{\circ} \mathrm{W}$ & 42 & AGAGE & 1 \\
\hline 4 & $\mathrm{CGO}$ & Cape Grim, Tasmania & $41.0^{\circ} \mathrm{S}$ & $145.0^{\circ} \mathrm{E}$ & 94 & AGAGE & 1 \\
\hline 5 & JUN & Jungfraujoch, Switzerland & $46.5^{\circ} \mathrm{N}$ & $8.0^{\circ} \mathrm{E}$ & 3580 & SOGE & 1 \\
\hline 6 & MTE & Monte Cimone, Italy & $44.2^{\circ} \mathrm{N}$ & $10.7^{\circ} \mathrm{E}$ & 2165 & SOGE & 1 \\
\hline 7 & ZEP & Zeppelin Station, Norway & $78.9^{\circ} \mathrm{N}$ & $11.9^{\circ} \mathrm{E}$ & 474 & SOGE & 1 \\
\hline 8 & HAT & Hateruma, Japan & $24.1^{\circ} \mathrm{N}$ & $123.8^{\circ} \mathrm{E}$ & 47 & NIES & $1.0100(1.0150)$ \\
\hline 9 & BRW & Pt. Barrow, Alaska & $71.3^{\circ} \mathrm{N}$ & $156.6^{\circ} \mathrm{W}$ & 8 & NOAA & $1.0212(1.0318)$ \\
\hline 10 & MLO & Mauna Loa, Hawaii & $19.5^{\circ} \mathrm{N}$ & $155.6^{\circ} \mathrm{W}$ & 3397 & NOAA & $1.0212(1.0318)$ \\
\hline 11 & NWR & Niwot Ridge, Colorado & $40.0^{\circ} \mathrm{N}$ & $105.5^{\circ} \mathrm{W}$ & 3018 & NOAA & $1.0212(1.0318)$ \\
\hline 12 & SMO & Cape Matatula, American Samoa & $14.3^{\circ} \mathrm{S}$ & $170.6^{\circ} \mathrm{W}$ & 77 & NOAA & $1.0212(1.0318)$ \\
\hline 13 & SPO & South Pole, Antarctica & $89.9^{\circ} \mathrm{S}$ & $24.8^{\circ} \mathrm{W}$ & 2810 & NOAA & $1.0212(1.0318)$ \\
\hline \multicolumn{8}{|c|}{ Low Frequency Observations } \\
\hline 14 & MHD & Mace Head, Ireland & $53.3^{\circ} \mathrm{N}$ & $9.9^{\circ} \mathrm{W}$ & 25 & NOAA & $1.0102(1.0153)$ \\
\hline 15 & CGO & Cape Grim, Tasmania & $41.0^{\circ} \mathrm{S}$ & $145.0^{\circ} \mathrm{E}$ & 94 & NOAA/NIES & $1.0102(1.0153)$ \\
\hline 16 & THD & Trinidad Head, California & $41.0^{\circ} \mathrm{N}$ & $124.0^{\circ} \mathrm{W}$ & 140 & NOAA & $1.0102(1.0153)$ \\
\hline 17 & HAT & Hateruma, Japan & $24.1^{\circ} \mathrm{N}$ & $123.8^{\circ} \mathrm{E}$ & 27 & NIES & $1.0064(1.0096)$ \\
\hline 18 & ALT & Alert, Northwest Territories, Canada & $82.5^{\circ} \mathrm{N}$ & $62.5^{\circ} \mathrm{W}$ & 210 & NOAA & $1.0102(1.0153)$ \\
\hline 19 & BRW & Pt. Barrow, Alaska & $71.3^{\circ} \mathrm{N}$ & $156.6^{\circ} \mathrm{W}$ & 11 & NOAA & $1.0102(1.0153)$ \\
\hline 20 & LEF & WLEF tower, Wisconsin & $46.0^{\circ} \mathrm{N}$ & $90.3^{\circ} \mathrm{W}$ & 470 & NOAA & $1.0102(1.0153)$ \\
\hline 21 & HFM & Harvard Forest, MA & $42.5^{\circ} \mathrm{N}$ & $72.2^{\circ} \mathrm{W}$ & 340 & NOAA & $1.0102(1.0153)$ \\
\hline 22 & NWR & Niwot Ridge, Colorado & $40.1^{\circ} \mathrm{N}$ & $105.6^{\circ} \mathrm{W}$ & 3472 & NOAA & $1.0102(1.0153)$ \\
\hline 23 & MLO & Mauna Loa, Hawaii & $19.5^{\circ} \mathrm{N}$ & $155.6^{\circ} \mathrm{W}$ & 3397 & NOAA & $1.0102(1.0153)$ \\
\hline 24 & KUM & Cape Kumukahi, Hawaii & $19.5^{\circ} \mathrm{N}$ & $154.8^{\circ} \mathrm{W}$ & 3 & NOAA & $1.0102(1.0153)$ \\
\hline 25 & SMO & Cape Matatula, American Samoa & $14.2^{\circ} \mathrm{S}$ & $170.6^{\circ} \mathrm{W}$ & 77 & NOAA & $1.0102(1.0153)$ \\
\hline 26 & PSA & Palmer Station, Antarctica & $64.9^{\circ} \mathrm{S}$ & $64.0^{\circ} \mathrm{W}$ & 10 & NOAA & $1.0102(1.0153)$ \\
\hline 27 & SPO & South Pole, Antarctica & $89.98^{\circ} \mathrm{S}$ & $102.0^{\circ} \mathrm{E}$ & 2841 & NOAA & $1.0102(1.0153)$ \\
\hline
\end{tabular}

We use the 3-D model output to estimate the sampling frequency and mismatch errors following the approach of Chen and Prinn (2006).

There is generally a lower uncertainty associated with the high frequency measurements (e.g., 1.5\% on average) due to their capability to better capture sub-monthly temporal variations and thus better define monthly means. Although the monthly means from flask measurements therefore have larger assigned errors (e.g., 2.4\% on average) than those from the high frequency measurements (i.e., they have larger error covariance matrices, $\mathbf{R}$; see Appendix A), the greater proximity of some of the flask sites to some of the emitting regions can make them more sensitive to those regions (i.e., they can have larger sensitivity matrices, $\mathbf{H}$; see Sect. 4) which can help offset the effects of larger $\mathbf{R}$ in the calculation of the Kalman gain matrix, $\mathbf{K}$, that determines the effectiveness of each measurement in improving the emission estimates (see Appendix A).

\section{The MATCH model}

The Model of Atmospheric Transport and Chemistry (MATCH) is an off-line transport model developed at NCAR (Rasch et al., 1997; Mahowald, 1996; Mahowald et al., 1997a, b). In this work, MATCH is driven by NCEP reanalysis meteorology. The specific meteorological data used for the model are temperature, surface pressure, meridional and zonal wind speeds and surface wind stresses, and the surface latent and sensible heat fluxes at regular (typically 6-h) intervals. All other meteorological parameters (e.g., vertical velocities, cloud fractions, and convective mass fluxes) are computed on-line based on these meteorological data. The horizontal resolution of the analysis data is chosen to be $\mathrm{T} 42$, or approximately $2.8^{\circ} \times 2.8^{\circ}(64 \times 128$ grid points $)$. Due to the very large number of simulations needed to compute model sensitivities to monthly emission pulses in the inverse modeling, T42 is a reasonable compromise between numerical efficiency and accuracy. In the vertical, MATCH uses 
a hybrid coordinate, which consists of a terrain-following sigma coordinate combined with (optional) constant pressure level values. The NCEP data are on 28 sigma levels. The model time step is $40 \mathrm{~min}$ for the T42 resolution. The archived data are linearly interpolated between the neighboring time intervals to obtain the values for each time step.

Although MATCH can be extended to simulate the complicated photochemistry in the atmosphere (e.g., Lawrence et al., 1999; von Kuhlmann et al., 2003; Lucas and Prinn, 2005), only simple chemistry using offline $\mathrm{OH}$ concentrations needs to be incorporated into the basic MATCH model for the simulation of $\mathrm{CH}_{3} \mathrm{Cl}$ because it is not a major sink for $\mathrm{OH}$ or source of $\mathrm{HO}_{\mathrm{x}}$. The predominant removal process in the troposphere for $\mathrm{CH}_{3} \mathrm{Cl}$ is oxidation by the $\mathrm{OH}$ radical, which is the primary oxidizing chemical in the atmosphere. The relevant reaction is (Sander et al., 2006):

$$
\mathrm{CH}_{3} \mathrm{Cl}+\mathrm{OH} \rightarrow \mathrm{CH}_{2} \mathrm{Cl}+\mathrm{H}_{2} \mathrm{O}
$$

The temperature-dependent rate constant for reaction with the $\mathrm{OH}$ radical is given in the Arrhenius form:

$$
k(T)=A \exp [(-E / R)(1 / T)]
$$

where $A$ is the pre-exponential factor $\left(=2.4 \times 10^{-12} \mathrm{~cm}^{3}\right.$ molecule $\left.\mathrm{s}^{-1} \mathrm{~s}^{-1}\right), \quad R \quad$ is the universal gas constant, $E$ is the activation energy $\left(\mathrm{J} \mathrm{mol}^{-1}\right)$ $(E / R=1250 \mathrm{~K})$ (Sander et al., 2006), and $T(\mathrm{~K})$ is the temperature. In the model simulation, $k(T)$ is updated each time step based on the ambient conditions (temperature, pressure, etc.) in the grid cells.

The offline $\mathrm{OH}$ fields chosen are from the output generated using the version of MATCH-MPIC described in Lawrence et al. (1999), Jöckel (2000), and von Kuhlmann et al. (2003). This MATCH version incorporates a full photochemical component, representing the major known sources (e.g., industry, biomass burning), transformations (chemical reactions and photolysis), and sinks (e.g., wet and dry deposition) for studies of ozone and hydrocarbons in the troposphere. Chen and Prinn $(2005,2006)$ used the monthly mean MATCH-MPIC 3-D OH fields at T63 resolution adjusted to fit global AGAGE methyl chloroform $\left(\mathrm{CH}_{3} \mathrm{CCl}_{3}\right)$ observations (we reduced these T63 fields to T42 for this work). Finally, a diurnal cycle linked to the solar zenith angle is further applied to the daily average $\mathrm{OH}$ concentrations interpolated by MATCH from the monthly mean $\mathrm{OH}$ concentrations. This ensures zero nighttime values while maintaining the daily average $\mathrm{OH}$ concentrations (Chen and Prinn, 2005, 2006). Since the annual and global average $\mathrm{OH}$ did not change much (within 3\%) over the period of 2000-2004 (Fig. 2, Prinn et al., 2005), we used annually repeating $\mathrm{OH}$ fields. This allows us to assess the effect of the interannually varying transport (captured in the NCEP data) on the concentrations of $\mathrm{CH}_{3} \mathrm{Cl}$.
In the stratosphere, $\mathrm{CH}_{3} \mathrm{Cl}$ is oxidized by the hydroxyl radical and also photodissociates. However, the stratospheric sink is small for $\mathrm{CH}_{3} \mathrm{Cl}$ (7.6\% of the total atmospheric loss, Cox et al., 2003), and most of the stratospheric loss arises from OH attack (Seinfeld and Pandis, 1998), which is accounted for by the above 3-D OH fields in MATCH. Photodissociation of $\mathrm{CH}_{3} \mathrm{Cl}$ in the stratospheric is neglected in the model due to its very small role relative to $\mathrm{OH}$ as a global sink of $\mathrm{CH}_{3} \mathrm{Cl}$.

\section{Methodology for inverse modeling}

The inversion methodology used follows the approach of Chen and Prinn (2006) and the detailed methodology is described in Appendix A. The method is based on the Kalman filter (Prinn, 2000), which is adapted to estimate timevarying fluxes at monthly resolution for transient sources and invariant aseasonal fluxes for more steady sources. For this purpose, it is adequate to use monthly mean observations to constrain the monthly surface fluxes. What we actually estimate are the magnitudes of the regional or global fluxes by location and/or process, assuming we know their spatial distributions within each region (referred to here as the reference or a priori maps). Specifically, the state vector $\boldsymbol{x}$ in the Kalman filter contains variables representing the regional or global magnitudes of the surface fluxes of $\mathrm{CH}_{3} \mathrm{Cl}$ for the time period of 2000-2004 with month-to-month variations allowed for seasonal processes. In the adaptation of the Kalman filter, the full state vector including the elements for the surface fluxes of the total 60 months is truncated when using the observations step by step (see Appendix A).

We use the MATCH model to compute the sensitivities (the matrix $\mathbf{H}$ ) of the mole fractions at different sites to the state vector elements by finite differences. A straightforward approach for computing $\mathbf{H}$ for an $n$-dimensional state vector $\boldsymbol{x}$ is to do a single model run with $n+1$ chemically identical (but separately labeled) chemical species. One of the chemical species uses a reference (e.g., a priori best estimate) of $\boldsymbol{x}$, while the other $n$ species use values of $\boldsymbol{x}$ with one element slightly perturbed from its reference value.

We use different procedures to generate the aseasonal and seasonal sensitivities. For aseasonal fluxes we perturb a single process/region above the reference level by $1 \%$ and run it over the entire data period. The sensitivities are then determined by subtracting the perturbation and reference runs, and then dividing by the total emission perturbation to produce a time series of sensitivities of the mole fractions in terms of parts per trillion (ppt)/(Gg yr $\left.{ }^{-1}\right)$. The aseasonal sensitivity elements thus contain the influence of all previous months from the very beginning of the period. For seasonal fluxes we calculate the sensitivities to each single month by perturbing a single process/region above the reference level for only that month and then tracking the tracer within the model after that month for a subsequent period over which the emission pulse 

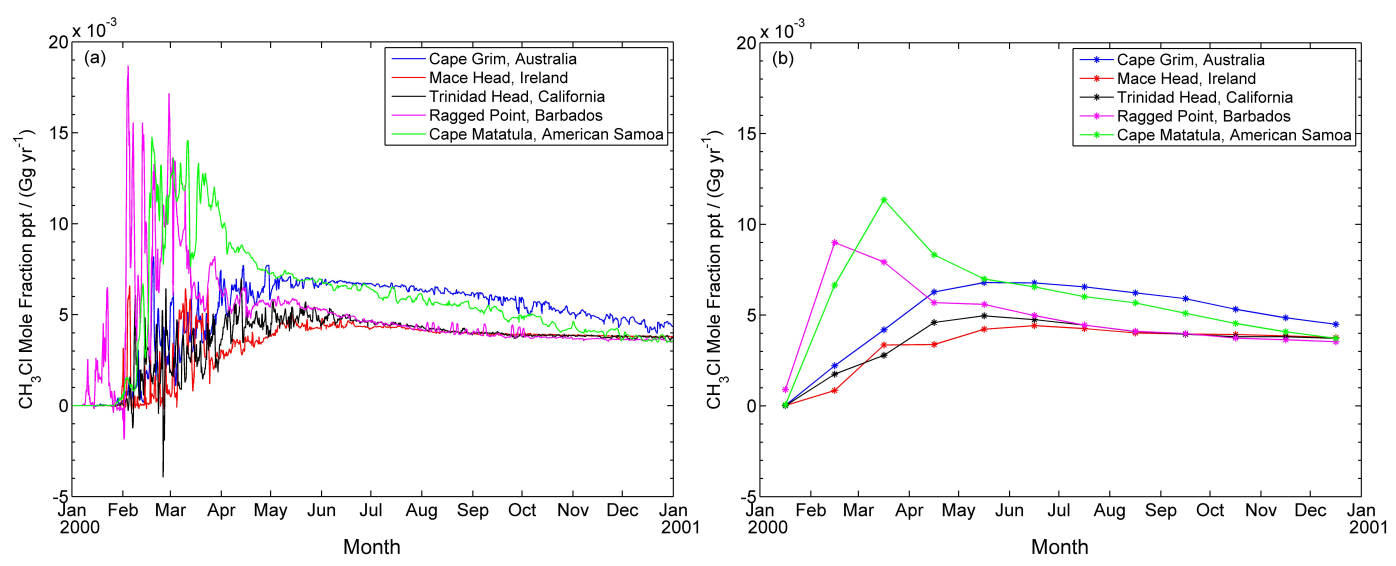

Fig. 2. MATCH-modeled sensitivities of $\mathrm{CH}_{3} \mathrm{Cl}$ (a) high frequency and (b) monthly mean mole fractions at each AGAGE site to a January 2000 emission pulse from African tropical plants. Eventually the mole fractions reach similar values for each site consistent with a $\mathrm{CH}_{3} \mathrm{Cl}$ emission pulse into a well-mixed atmosphere. In addition to dispersion, the sensitivities are affected by a slow $\mathrm{CH}_{3} \mathrm{Cl}_{\text {decrease due to }}$ reaction with the $\mathrm{OH}$ radical.

decays due to atmospheric dispersion and chemical loss. We call this the "unit pulse method". For the period of 20002004 we have performed 5 years $\times 12$ months $=60$ monthly pulse runs, each being a separate multi-tracer run starting at a different month. The global mixing (dispersion) time in the model is about one year (Chen and Prinn, 2006). Therefore we run each of the 60 monthly pulses for 12 months instead for the full 2000-2004 period with the pulse affecting only the global average after 12 months.

Figure 2 shows examples of calculated sensitivities for individual sites to an individual monthly pulse as functions of time, specifically a January 2000 uniform emission pulse of $10 \mathrm{Gg} \mathrm{yr}^{-1}$ from the tropical plants in Africa. Results are shown at: (a) the model time resolution and (b) the monthly time resolution of the deduced fluxes. The sensitivities are largest in the first 3-4 months and then decrease because of dispersion due to atmospheric mixing. Responses at different sites show different behaviors because of their different location relative to the source region and due to the global wind patterns. Ragged Point, Barbados and Cape Matatula, American Samoa are located in the tropical east wind region and are downwind of Africa, and therefore respond rapidly to the plant emission pulse with sharp peaks. Ragged Point is closer to Africa than Cape Matatula, and shows the more rapid response. The other three sites are either further away from the source region and/or not in the same wind regime as the source region. Therefore their responses are less sharp and relatively slow. All the responses include continuous decreases due to reaction of $\mathrm{CH}_{3} \mathrm{Cl}$ with the $\mathrm{OH}$ radical. Note that the responses at different sites tend to converge to a single value after one year which is consistent with an emission pulse into a well-mixed atmosphere. These monthly seasonal sensitivities, along with the monthly aseasonal sensitivities, are used to construct the time dependent sensitivity matrix $\mathbf{H}$ used in the inversions.

\section{Inversion for methyl chloride}

In this section we present inversion results for $\mathrm{CH}_{3} \mathrm{Cl}$ surface fluxes using the methodology described in Sect. 4. The optimized surface fluxes include seasonal, annual, and interannual values for specific emitting and depleting processes and regions. The inversion results are presented and discussed in sequence, with a particular emphasis on possible emission and depletion anomalies associated with the 2002/2003 globally wide-spread heat and drought which was partly caused by the minor 2002/2003 El Niño event. We also test the sensitivity of the inversion results to different combinations of observations.

\subsection{Definition of the state vector and its a priori flux maps}

In the inverse modeling methodology, a priori flux distributions are needed as the initial guesses for the unknown surface fluxes. It is important to know the spatial distributions of the reference regional or process-based fluxes as accurately as possible, but not their magnitudes or time dependence since these will be estimated in the inversion.

Considerable effort has been put into estimating anthropogenic and natural emissions of reactive chlorine to the atmosphere (e.g., Graedel and Keene, 1995, 1996; Singh, 1995; Watling and Harper, 1998; Khalil, 1999; Keene et al., 1999). The Reactive Chlorine Emissions Inventory (RCEI) carried out under the auspices of the International Global Atmospheric Chemistry Program's Global Emissions Inventory Activity (GEIA) (Graedel and Keene, 1999) is particularly relevant. It provides high resolution $\left(1^{\circ} \times 1^{\circ}\right.$ latitude, longitude) annual emission fields for major reactive tropospheric $\mathrm{Cl}$ species integrated across source types (terrestrial biogenic and oceanic emissions, biomass burning, industrial emissions, fossil-fuel combustion, incineration, etc.) for the 

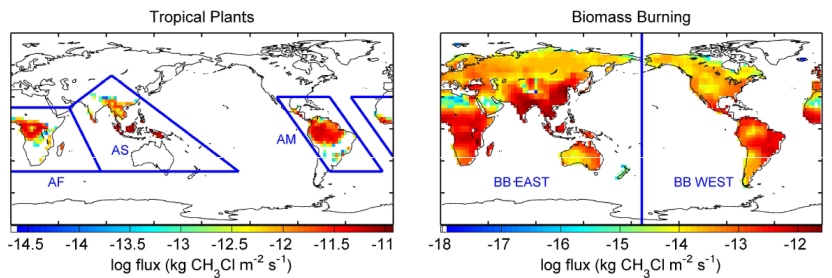

Oceans
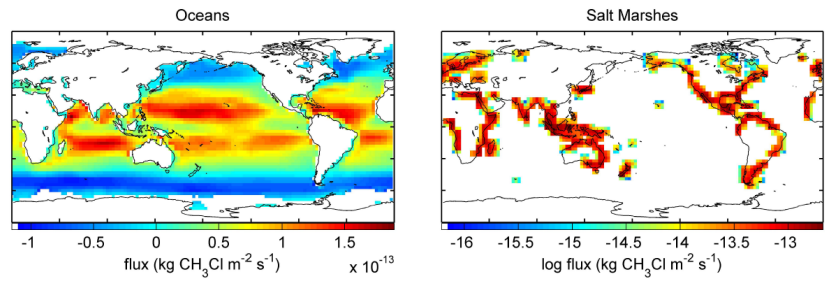

Fig. 3. Annual average distributions of reference $\mathrm{CH}_{3} \mathrm{Cl}$ emissions. Emission magnitudes and patterns vary by month. Tropical plants (America, Asia, and Africa) and biomass burning (East and West) have been further subdivided for the inversion. Note that the maps are on a log scale except for the oceans which have a linear scale.

reference year 1990. Lee-Taylor et al. (2001) modified and extended these estimates in their 3-D modeling of $\mathrm{CH}_{3} \mathrm{Cl}$ by parameterizing month by month seasonal variations. These emissions represent our best initial guess of $\mathrm{CH}_{3} \mathrm{Cl}$ fluxes before optimization of individual regions or processes.

As suggested by Yokouchi et al. (2002), $\mathrm{CH}_{3} \mathrm{Cl}$ emissions from tropical plants might be the largest known source, but they are not included in this GEIA inventory. We assumed in this study that tropical plants have a significant role in $\mathrm{CH}_{3} \mathrm{Cl}$ production and incorporated this process into the inversion to estimate its magnitude and seasonality on regional scales. For our reference emissions, we attribute the imbalance of the global $\mathrm{CH}_{3} \mathrm{Cl}$ budget between known sources and sinks (Cox et al., 2003) to this tropical plant process and spatially distribute the resulting global emission estimate proportionally to published net primary productivity (NPP) estimates of tropical plant ecosystems in each MATCH grid square (McGuire et al., 2001). The measurements of Yokouchi et al. (2000) show close correlations between local enhancements of $\mathrm{CH}_{3} \mathrm{Cl}$ and a biogenic compound $\alpha$-pinene, emitted by tropical plants. Foliar emissions of $\alpha$-pinene have been argued to be proportional to foliar density, temperature, and available light (Guenther et al., 1995). Therefore it is reasonable to assume that $\mathrm{CH}_{3} \mathrm{Cl}$ fluxes are also proportional to the foliar density of the emitting plants. Guenther et al. (1995) further argue that foliar density is proportional to the NPP of the relevant species. The monthly tropical plant NPP database $\left(0.5^{\circ} \times 0.5^{\circ}\right.$ latitude, longitude $)$ estimated by McGuire et al. (2001) represents the net production of organic matter in tropical ecosystems and accounts for the influences of atmospheric $\mathrm{CO}_{2}$, and seasonal and climatic changes in temperature, precipitation, and available light.

These flux maps have been interpolated to the MATCH T42 grid system $\left(2.8^{\circ} \times 2.8^{\circ}\right)$ while conserving their global
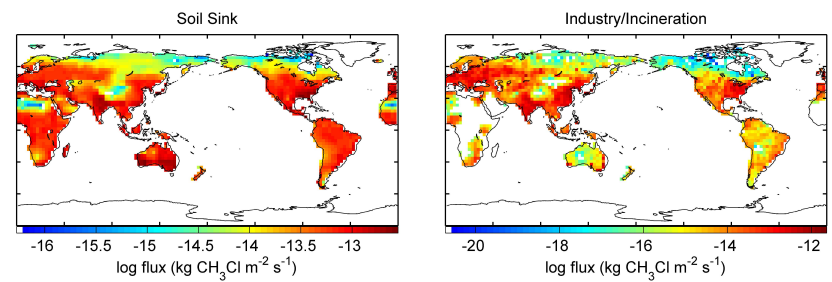

Wood-rotting Fungi
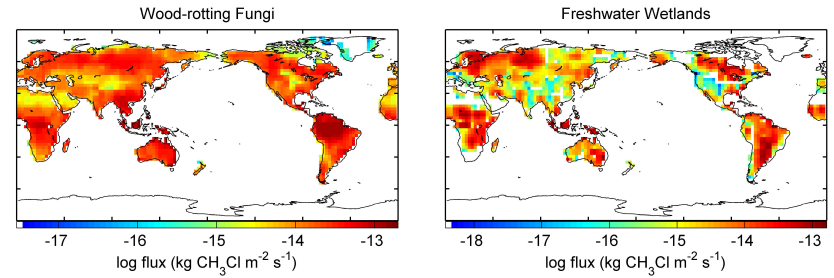

Fig. 4. Annual average distributions of additional $\mathrm{CH}_{3} \mathrm{Cl}$ monthly varying emissions and the soil sink. Note that the small industrial, incineration and wetland sources are assumed to be equal to their reference values and are not estimated. Seasonal variability of the small fungal emissions is not considered in the inversion.

magnitudes by using the SCRIP (Spherical Coordinate Remapping and Interpolation Package) software. Figures 3 and 4 show the annually averaged reference spatial distributions of the surface fluxes from tropical plants, oceans, biomass burning, anthropogenic activities, and other processes. Tropical emissions are divided into three regions, America, Asia, and Africa, for the inversions, denoted as Trop AM, Trop AS, and Trop AF, respectively. Emissions from biomass burning are further divided into Western (North and South America) and Eastern (Africa (including West Africa), Europe (including Spain), Asia, and Australia) regions, denoted as BB West and BB East, respectively. Oceans are a source at lower latitudes and a sink at higher latitudes for $\mathrm{CH}_{3} \mathrm{Cl}$ and correction factors for its reference map are only estimated globally. We also estimate correction factors for the maps of global emissions from salt marshes and the global uptake rates by soils (soil sink). Emissions from freshwater wetlands are very small and are kept at their reference values with assumed seasonal changes that are not estimated here. Seasonal variations of the relatively small fungal emissions are not considered here (as in Lee-Taylor et al., 2001) and its global emissions are solved only as an aseasonal flux. The small annual industry/incineration flux is not estimated here because of its spatial correlation with the fungal emissions. The corresponding state vector at time $k$ can be expressed as:

$\boldsymbol{x}_{k}=\left[\begin{array}{l}\boldsymbol{X}_{k}^{\mathrm{as}} \\ \boldsymbol{X}_{k}^{\mathrm{s}} \\ \boldsymbol{X}_{k-1}^{\mathrm{s}} \\ \cdots \\ \boldsymbol{X}_{k-T}^{\mathrm{s}}\end{array}\right]$ 
Where $T=11$ months (see Appendix A),

$$
\boldsymbol{X}_{k}^{\text {as }}=x_{k}^{\text {fungal }} \text {, and } \boldsymbol{X}_{k}^{\mathbf{s}}=\left[\begin{array}{c}
x_{k}^{\text {tropam }} \\
x_{k}^{\text {tropas }} \\
x_{k}^{\text {tropaf }} \\
x_{k}^{\text {bbeast }} \\
x_{k}^{\text {bbwest }} \\
x_{k}^{\text {ocean }} \\
x_{k}^{\text {salt }} \\
x_{k}^{\text {soil }}
\end{array}\right]
$$

We use data and calculate estimates for the period from 2000 to 2004 (total of 60 months). The global magnitudes of the reference emissions and their mode of incorporation in the state vector are listed in Table 2. The a priori errors for the state vector elements are $\pm 30 \%$ to $\pm 50 \%$ of their reference values. If both high frequency in situ data and low frequency flask data are available for the same site, the high frequency measurements were chosen as they capture intramonthly temporal variations much better.

\subsection{State vector evolution}

The equations used in the Kalman filter inversions are given in Appendix A (Prinn, 2000). There are hundreds of monthly flux elements in the state vector, but to illustrate the inversion process we focus here on a subvector representing a single month of fluxes (specifically September 2002). Figure 5 shows the evolution of this subvector, or equivalently how the estimates for the fluxes in a given single month change with each new month of data. As mentioned before, only 12 months of subsequent observations are used to constrain the fluxes of a given single month. The adjustments to the reference value (unity) are shown, so the initial value for each seasonal process is therefore zero with a generous a priori (blue) error bar of either $\pm 30 \%$ or $\pm 50 \%$ depending on our subjective estimate of the quality of the a priori data and the expected year-to-year variability. With each new month of observations, the adjustments change and the error decreases. The amount of the error decrease depends on the errors in the data ( $\mathbf{R}$ matrix, see Appendix A) and on the sensitivities of each observing station to the emissions ( $\mathbf{H}$ matrix, see Appendix A) for each emission region or process. Note that the changes and the error reductions for a given process are greatest in the first few months, because the strongest sensitivities of the observations to the emission pulse occur in that time frame. In the final few months, the estimated flux values and uncertainties stabilize even with the addition of new data. The optimized inversion results for September 2002 fluxes are the final values in Fig. 5. These final (a posteriori) values represent the adjustments to the reference (a priori) fluxes that minimize the estimation error variances. As noted earlier, because only 12 months of data have been used, these final values are phased out of the inversion and stored when a new subvector (in this case representing September 2003
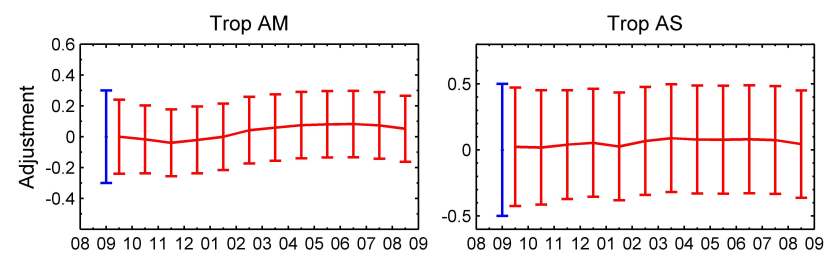

Trop AF

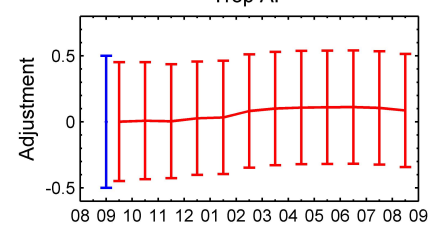

BB West
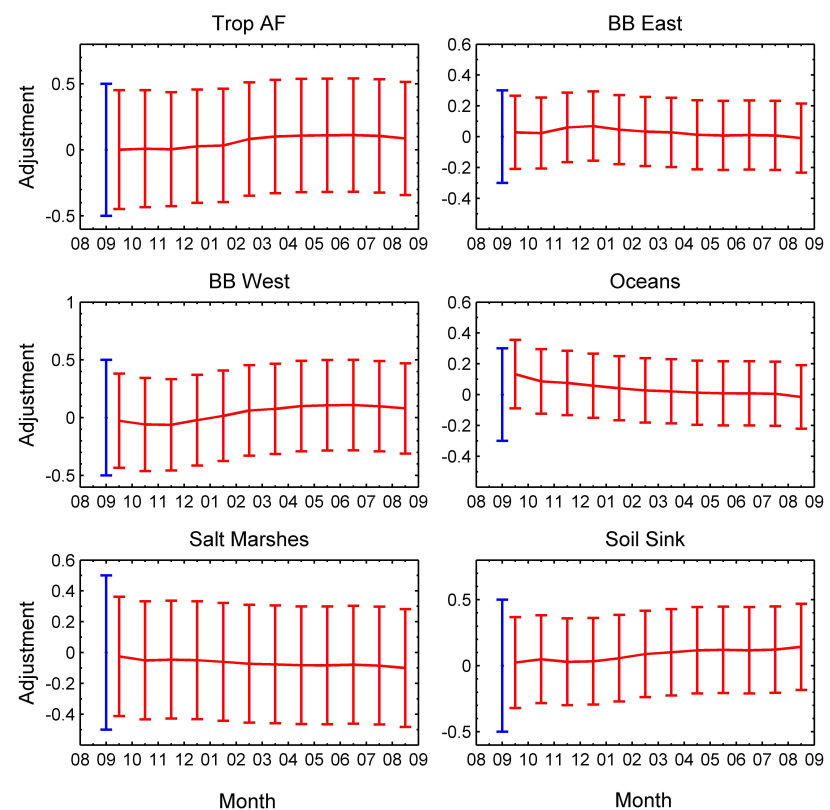

Oceans

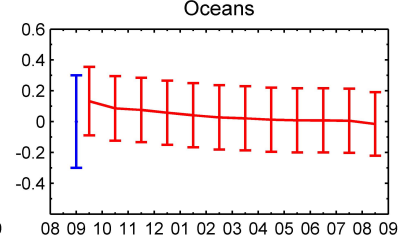

Soil Sink

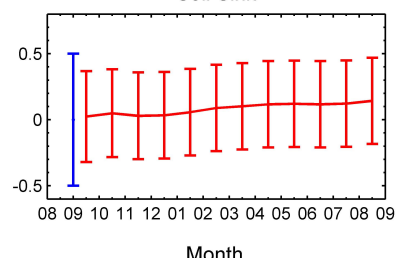

Month

Fig. 5. The recursive estimation of $\mathrm{CH}_{3} \mathrm{Cl}$ surface fluxes for a single month (September 2002) obtained with the use of monthly observations from September 2002 to August 2003 (horizontal axis). The vertical axis corresponds to the dimensionless adjustment from the reference value (unity). The blue line shows the a priori error bar (either \pm 0.3 or \pm 0.5 ) for the September 2002 surface flux. The final optimized results are taken as the values at the last step at which time the inversion has stabilized.

fluxes) enters the inversion process. The optimized estimates are then tested using a forward run of MATCH which is compared to the observations. These tests will be presented after the inversion results.

\subsection{Inversion results}

Here we present the results with all of the available observations used in the Kalman filter (i.e., all AGAGE, NOAA, NIES and SOGE in situ data plus all NOAA and NIES flask data at sites where there are no in situ measurements). We have also tested the sensitivities of the inversion results to the chosen data by using several different subsets of the observations from the various networks (see Sect. 5.3.2).

Figure 6 shows the optimized monthly fluxes (red lines) from January 2000 to December 2004, compared to the annually repeating reference values (blue lines). There are significant deviations from the reference case for some emission regions and processes. Overall there are larger seasonal 
Table 2. Reference annual average strengths of the sources and sinks of $\mathrm{CH}_{3} \mathrm{Cl}$ and their incorporation in the inversion. $\mathrm{Y}=\mathrm{YES}$ and $\mathrm{N}=\mathrm{NO}$.

\begin{tabular}{llll}
\hline Source/Sink Type (reference) & Estimated Monthly & Strength $\left(\mathrm{Gg} \mathrm{yr}^{-1}\right)$ & In State Vector? \\
\hline Biomass burning (Lobert et al., 1999) & Y & 918 & Y (2 regions) \\
$\begin{array}{l}\text { Wood-rotting fungi (Watling and Harper, 1998; } \\
\text { Khalil et al., 1999; Moore et al., 2005) }\end{array}$ & N & 128 & Y \\
$\begin{array}{l}\text { Industry/incineration (McCulloch et al., 1999) } \\
\text { Oceans, NCEP 10m winds (Khalil et al., 1999; }\end{array}$ & Y & 162 & N (reference) \\
$\begin{array}{l}\text { Lee-Taylor et al., 2001) } \\
\text { Salt marshes (Rhew et al., 2000) }\end{array}$ & Y & 477 & Y \\
$\begin{array}{l}\text { Soil sink (Keene et al., 1999; Khalil and Ras- } \\
\text { mussen, 1999) }\end{array}$ & Y & 170 & Y \\
$\begin{array}{l}\text { Freshwater wetlands (Varner et al., 1999) } \\
\text { Tropical plants (Yokouchi et al., 2002) }\end{array}$ & Y & -256 & Y \\
$\begin{array}{l}\text { Total source (soil sink excluded) } \\
\text { Net source (soil sink subtracted) }\end{array}$ & Y & 48 & N (reference) \\
\hline
\end{tabular}

oscillations than seen in the reference for almost all of the seasonal processes.

The optimized fluxes also show significant interannual variability, of which the flux anomalies for the period of 2002/2003 for several processes are noteworthy. There were unusual 2002/2003 decreases in $\mathrm{CH}_{3} \mathrm{Cl}$ emissions from American tropical ecosystems, unusually high emissions from the eastern biomass burning source in the late spring of 2002/2003, unusually large emissions from the western biomass burning source in late 2002, an anomalous emission rise from global salt marshes in the summer of 2002 through early 2003, and an unusual reduction in the global soil uptake in the northern summer of 2003.

These anomalies are likely attributable to the significant 2002/2003 globally wide-spread heat waves and droughts which were partly associated with the 2002/2003 El Niño that lasted from September 2002 to August 2003. Recent studies show a consistent link between El Niño and drought in the tropics (Lyon, 2004) and mid-latitudes (Zeng et al., 2005). While the El Niño during this time was moderate compared to the extreme 1997/1998 El Niño, the period of 2002/2003 appears unusual because global land precipitation was very low, leading to very dry and hot conditions (Knorr et al., 2007).

Ciais et al. (2005) deduced that there was a reduction in net plant primary productivity apparently caused by the heat and drought in 2003. This reduction in primary productivity is the probable cause of the reductions in tropical plant emis- sions because of the correlation of primary productivity and foliar emission as noted earlier (Guenther et al., 1995).

The extremely dry and hot season might also lead to increased insect damage to vegetation and increased susceptibility of the boreal biome to fire (Kobak et al., 1996; Ayres and Lombardero, 2000). Using measurements of burned forest area in Central Siberia (approx. $79-119^{\circ} \mathrm{E}, 51-78^{\circ} \mathrm{N}$ ), Balzter et al. (2005) showed that 2002 and 2003 were the two years with the largest fire extent in Central Siberia since 1996. This is the region within our Biomass Burning (BB) East map. These enhanced fire events are expected to increase $\mathrm{CH}_{3} \mathrm{Cl}$ emissions. This is supported by the study of Simmonds et al. (2005), which shows that Siberian fires caused a growth rate anomaly in Mace Head baseline $\mathrm{CH}_{3} \mathrm{Cl}$ values in 2002-2003.

Methyl chloride is produced in coastal salt marsh regions by plants or microflora intimately associated with the plants, with greater emissions in the growing season than in the nongrowing season (Rhew et al., 2000). For these regions, temperature plays a more dominant role than the moisture in plant growth, because tidal sea water always provides the required soil moisture for plants to grow. Therefore the anomalous hot summers might have led to increased salt marsh plant growth in the summer of 2002, thus increasing the production of $\mathrm{CH}_{3} \mathrm{Cl}$. 

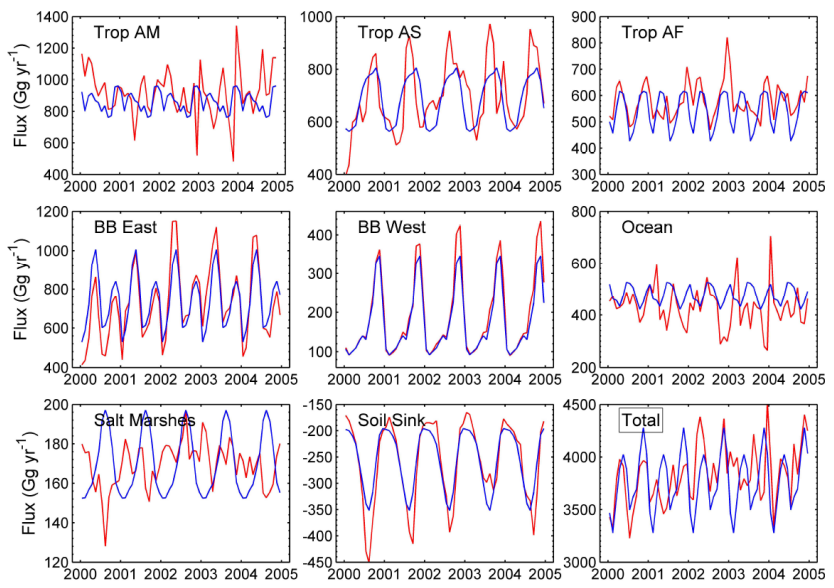

Fig. 6. Inversion results for the eight seasonally varying processes for emissions of $\mathrm{CH}_{3} \mathrm{Cl}$. Blue lines show the reference magnitudes, which are annually repeating. Red lines show the optimized estimates, which show interannual variability. The total value is the sum of the emissions from the eight seasonal processes, the assumed time invariant aseasonal fungal emissions, and the reference industrial and wetland emissions.

Methyl chloride is degraded in soils by microbial activity. Lee-Taylor et al. (2001) parameterized soil uptake of $\mathrm{CH}_{3} \mathrm{Cl}$ by assuming proportionality to a methyl bromide $\left(\mathrm{CH}_{3} \mathrm{Br}\right)$ soil sink extrapolation (Lee-Taylor et al., 1998). The latter approach used $\mathrm{CH}_{3} \mathrm{Br}$ observations of Shorter et al. (1995) and assumed a microbial activity/soil temperature relationship (Cleveland et al., 1993; Holland et al., 1995) with stronger microbial activity at higher temperatures. This is why the reference global soil uptake rate is greatest in the summer of the Northern Hemisphere. However, the inversion indicates an unexpected decrease of the soil sink in the summer of 2003. The microbial activity/soil temperature relationship neglects the influence of soil moisture on microbial activity and uptake efficiency. Laboratory and field experiments by Shorter et al. (1995) did show a general relationship of decreasing $\mathrm{CH}_{3} \mathrm{Br}$ uptake activity with decreasing moisture and organic matter content. Therefore the anomalously low global soil uptake might have been caused by the extremely widespread drought conditions in 2003.

If future climate in the Northern Hemisphere evolves toward increasingly dry and hot summers caused by a substantial increase in variability of temperature and precipitation in response to greenhouse forcing (e.g., Schär et al., 2004), this may lead to increased probability of decreased NPP (and hence decreased tropical $\mathrm{CH}_{3} \mathrm{Cl}$ emissions), increased emissions from biomass burning, increased salt marsh plant emissions, and decreased soil organic matter and microbial activity (and hence decreased $\mathrm{CH}_{3} \mathrm{Cl}$ consumption by soils).

Figure 7 shows the corresponding uncertainties of the optimized estimates by superimposing the optimized (a posteriori) uncertainties (red bars) on top of the reference (a priori) uncertainties (blue bars). Note that the inversion always re-
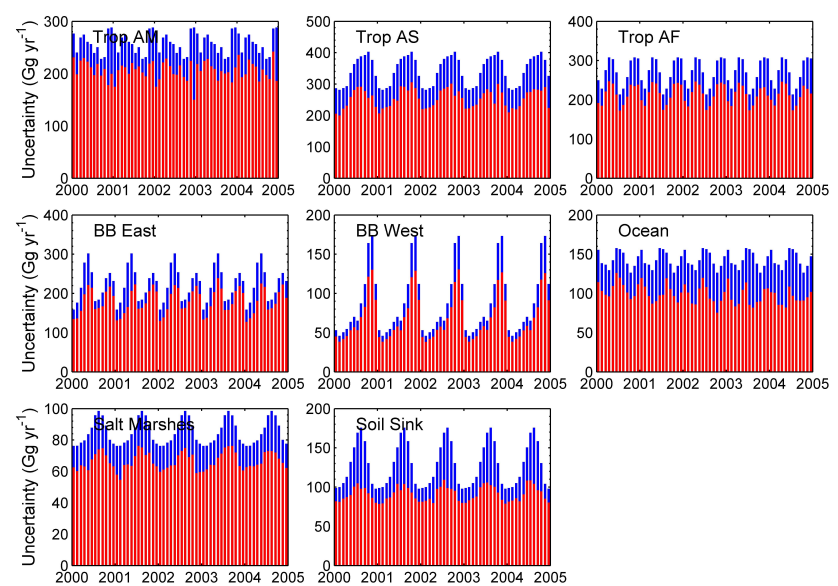

Fig. 7. The corresponding uncertainties ( $1 \sigma$ error bars) of the inversion results in Fig. 6, with the optimized error bars (red) superimposed upon the reference error bars (blue).

duces the initial uncertainty by amounts depending on the value of the observations in constraining each emission process or region. Uncertainties for Trop AS plants, Oceans, and the Soil Sink decrease the most, those for Trop AF plants, BB West, and Salt Marshes have smaller reductions, while those for Trop AM plants and BB East have the least reductions, relative to their corresponding initial uncertainties.

As noted in Sect. 2, we also carried out inversions using adjustments to the best-estimate calibration ratios between the networks (see Table 1), in order to ascertain the sensitivity of our inversions to these ratios. The sensitivity is very small with the average root-mean-square percentage difference between the emission estimates with and without the adjustments being only $2 \%$. This is due both to the small differences between the network calibrations, and to the dominant contribution of the mismatch or representation error on the overall measurement error used in the inversions.

The mole fraction variations at each site depend on its proximity to the various source and sink regions, the $\mathrm{OH}$ variations and the atmospheric circulation. The contributions from each individual source or sink can be computed from the relevant elements of $\mathbf{H}$ and the optimized $\boldsymbol{x}$. For example, the multi-year average percentage contributions to the mole fraction variations at CGO (Tasmania) are 5, 11, 7, 6, 6, 2, 3, 3 and $-3 \%$ from Fungi, Trop AM, Trop AS, Trop AF, BB East, BB West, Oceans, Salt Marshes and Soil Sink, respectively, with influences of industry and wetlands being minor. The remaining percentage is due to the imposed $\mathrm{OH}$ sink variations and to the slow evolution of the global background mole fraction attributed to emissions more than one year in the past. 

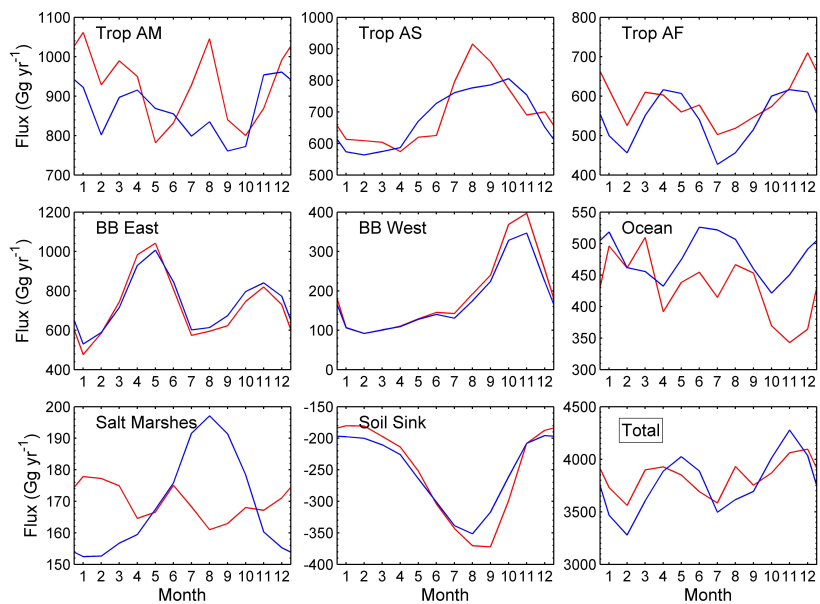

Fig. 8. Five-year averaged results for the 8 seasonally varying emission processes of $\mathrm{CH}_{3} \mathrm{Cl}$. Blue lines show the reference magnitudes. Red lines show the optimized estimates.

\subsubsection{Average seasonal results}

To obtain a single representative seasonal cycle for each seasonally varying process, we calculated the arithmetic average of each month during the five year period. The corresponding associated uncertainties are

$\bar{\sigma}_{t}=\sqrt{\frac{\sum_{1}^{N} \sigma_{t, n}^{2}}{N}}$

where $t$ represents a particular month (e.g., January) and $n=$ 1 to $N=5$, for the five years of the inversion.

Figure 8 shows the averaged seasonal cycle results (red lines) compared to the reference ones (blue lines), and Fig. 9 shows their corresponding uncertainties. For the tropical plant emissions, the seasonal variations differ somewhat from the reference for the three regions, with the most significant differences occurring for the tropical American region which exhibits two emission peaks. One is in January (its reference value shows a peak in December) and the other one is in August. As noted earlier, the variability in tropical emissions is the net of the combined influences of the variables atmospheric temperature, precipitation, and available light, and therefore does not generally reflect the annual cycle of one of these variables alone. While emissions from tropical plants in Africa have a maximum in December, they have a minimum in July. This is probably because at this time Africa is very dry and plant growth activity (NPP) is inhibited.

Deduced biomass burning emissions retain approximately the temporal variations present in their a priori (reference) values. To study the seasonal behavior of the biomass burning source, we examine in Fig. 10 the partitioning of the deduced seasonal cycles of the Eastern and Western sources
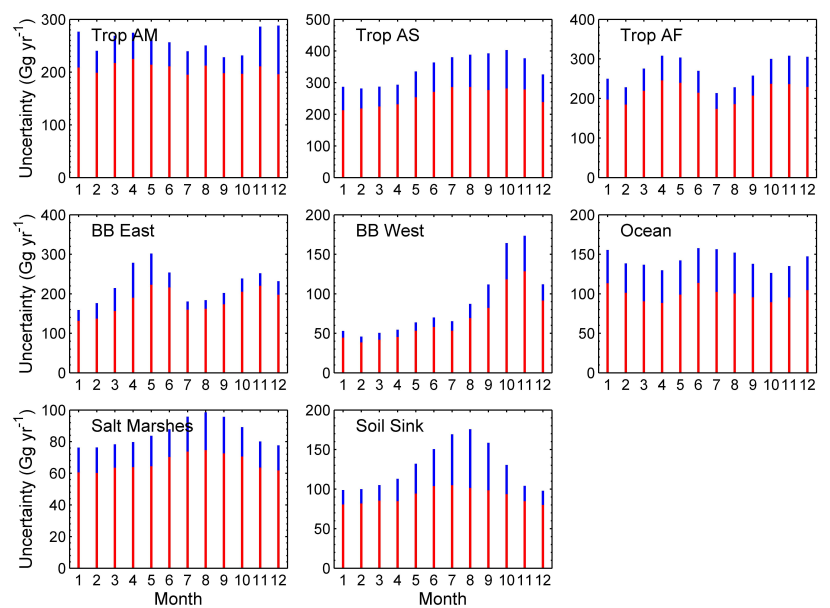

Fig. 9. The corresponding uncertainties ( $1 \sigma$ error bars) of the inversion results in Fig. 8, with the optimized error bars (red) superimposed upon the reference error bars (blue).

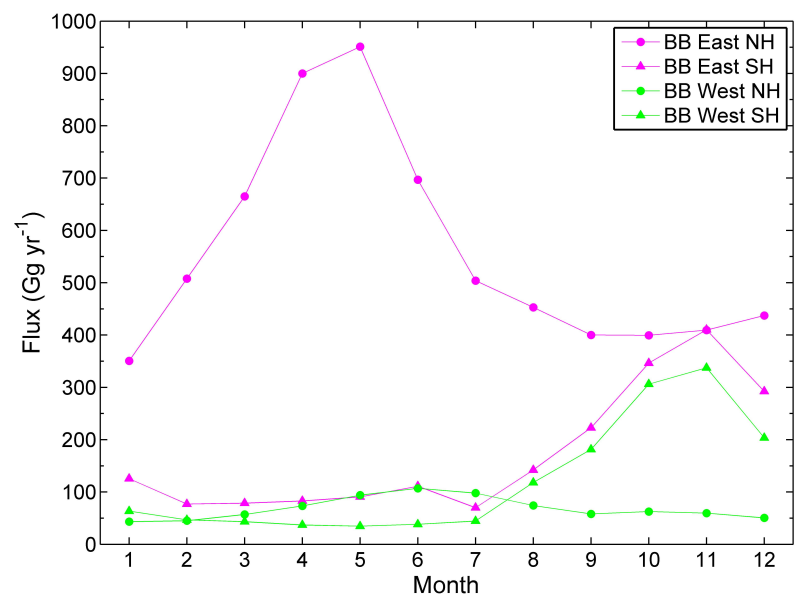

Fig. 10. Partitioning of the deduced average seasonal cycles of the Eastern and Western biomass burning sources into the Northern and Southern Hemispheres. Note the dominance of the Eastern Northern Hemispheric emissions of $\mathrm{CH}_{3} \mathrm{Cl}$. Also note the emission peaks of the Northern and Southern Hemispheres occur in the respective spring seasons consistent with dry conditions leading to increase biomass burning activity.

(BB East and BB West in Fig. 8) into the Northern and Southern Hemispheres. Note that the Northern spring (April and May) peak of the Eastern biomass burning source originates from the Northern Hemisphere, and that the Southern spring (October and November) peak originates from the Southern Hemisphere. The Western biomass burning emission peak in Southern spring (November) originates from Southern America. For both Hemispheres the biomass burning emissions are strongest during the spring season which is associated with dry conditions and strong biomass burning activity (Hao and Liu, 1994). Relative to the reference, the inversion increased the BB Eastern emission peak in the 
Table 3. Reference and optimally estimated five-year averaged surface fluxes and their errors for aseasonal and seasonal processes $\left(\mathrm{Gg}^{\mathrm{yr}}{ }^{-1}\right)$ obtained by using different combinations of data from the sampling networks. Total emissions are the sum of the estimated sources, the constant industrial source, and the annual average wetland emissions (with soil sink excluded).

\begin{tabular}{|c|c|c|c|c|c|c|c|c|c|}
\hline Flux type & Reference & $\begin{array}{l}\text { (1) In situ + NOAA } \\
\& \text { NIES flask }\end{array}$ & $\begin{array}{l}\text { (2) Case (1) without } \\
\text { in situ } \mathrm{SPO}^{2}\end{array}$ & (3) In situ ${ }^{3}$ & $\begin{array}{l}\text { (4) In situ without } \\
\mathrm{SPO}^{4}\end{array}$ & (5) Only AGAGE 5 & $\begin{array}{l}\text { (6) Only NOAA } \\
\text { flask }^{6}\end{array}$ & $\begin{array}{l}\text { (7) In situ without } \\
\text { NIES }^{7}\end{array}$ & $\begin{array}{l}\text { (8) In situ without } \\
\text { SOGE }^{8}\end{array}$ \\
\hline Fungal & $128 \pm 153$ & $165 \pm 117$ & $148 \pm 117$ & $206 \pm 122$ & $169 \pm 123$ & $186 \pm 132$ & $91 \pm 119$ & $206 \pm 122$ & $212 \pm 123$ \\
\hline Tropical & $2089 \pm 511$ & $2197 \pm 394$ & $2211 \pm 395$ & $2092 \pm 398$ & $2121 \pm 400$ & $2130 \pm 435$ & $2360 \pm 406$ & $2093 \pm 399$ & $2088 \pm 400$ \\
\hline Bio. Burn. & $918 \pm 247$ & $917 \pm 198$ & $939 \pm 199$ & $938 \pm 206$ & $974 \pm 207$ & $910 \pm 226$ & $922 \pm 201$ & $937 \pm 207$ & $931 \pm 208$ \\
\hline Oceans & $477 \pm 143$ & $430 \pm 100$ & $440 \pm 101$ & $427 \pm 112$ & $452 \pm 117$ & $475 \pm 133$ & $480 \pm 106$ & $427 \pm 112$ & $426 \pm 113$ \\
\hline Salt marsh & $170 \pm 85$ & $170 \pm 67$ & $172 \pm 67$ & $175 \pm 68$ & $179 \pm 68$ & $171 \pm 69$ & $171 \pm 68$ & $175 \pm 68$ & $175 \pm 68$ \\
\hline Soil sink & $-256 \pm 131$ & $-259 \pm 92$ & $-254 \pm 92$ & $-245 \pm 103$ & $-238 \pm 103$ & $-258 \pm 108$ & $-260 \pm 89$ & $-245 \pm 103$ & $-248 \pm 104$ \\
\hline Total Emi. & $3992 \pm 625$ & $4089 \pm 471$ & $4119 \pm 473$ & $4049 \pm 483$ & $4106 \pm 486$ & $4082 \pm 529$ & $4233 \pm 485$ & $4049 \pm 484$ & $4041 \pm 485$ \\
\hline
\end{tabular}

${ }^{1}$ Using data from all in situ sites, the NIES HAT flask site, and the PSA, KUM, ALT, LEF, and HFM NOAA flask sites. This is the "best estimate" inversion case shown in the figures.

2 Inversion case (1) with NOAA in situ SPO site excluded.

${ }^{3}$ Using data from all in situ sites listed in Table 1.

${ }^{4}$ Inversion case (3) with NOAA in situ SPO site excluded.

5 Using data only from AGAGE sites MHD, THD, RPB and CGO (the SMO measurements began after the time period of 2000-2005 addressed here)

${ }^{6}$ Using data from all 13 NOAA flask sites listed in Table 1.

7 Inversion case (3) with NIES data excluded.

8 Inversion case (3) with SOGE data excluded.

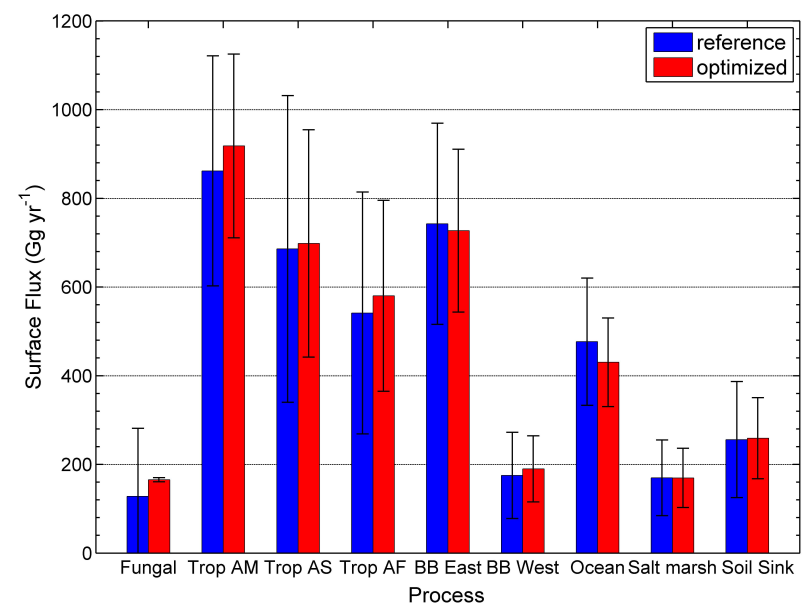

Fig. 11. Annual average $\mathrm{CH}_{3} \mathrm{Cl}$ surface flux magnitudes. Shown are the reference (blue bars) and optimized (red bars) values with their $1 \sigma$ error bars (black). The errors on the references are the assumed a priori inversion uncertainties of $\pm 30 \%$ to $\pm 50 \%$.

Northern Hemisphere in spring, and decreased the BB Eastern emission peak in the Southern Hemisphere in spring. The inversion also increased the BB Western emission peak in the Southern Hemisphere in spring.

Global ocean optimized emissions retain some of the seasonal variability seen in the reference, but with an overall reduction. The highest emission rates occur during the spring, resulting from the combined effects of the high monthly mean wind speeds and sea surface temperatures (Lee-Taylor et al., 2001). Compared to the reference values, emissions from global salt marshes are deduced to have a weak semiannual rather than a strong annual cycle. Finally, the peak in the global soil sink shifts from August to September.

\subsubsection{Average annual results}

The inversion results are finally averaged over the entire period between 2000-2004 to illustrate the global budget of $\mathrm{CH}_{3} \mathrm{Cl}$ (Fig. 11 and Table 3). We have aggregated the regional tropical plant and biomass burning emissions in Table 3; their individual regional fluxes are listed in Table 4. The multi-year averages for the seasonal processes are derived by averaging the results shown in Fig. 6. The inversion has directly solved for the aseasonal fungal process emissions as multi-year average values. Figure 11 and Table 3 also include the optimized emission errors, which are always less than the reference errors due to their reduction by the observations in the Kalman filter. For the seasonal processes, Eq. (3) has been extended to all months to determine the annual average errors. In Fig. 11, the aseasonal fungal uncertainty is taken from the last step of the Kalman filter. Note that the final error for the fungal emission estimate is much smaller than for the seasonal flux estimates. This is because the inversion solves the global fungal emission as a time-invariant variable over the entire period, thus allowing error reduction at every monthly time step. To provide a more realistic uncertainty estimate for the fungal emissions, we have multiplied the initial uncertainty estimate by the averaged percentage standard deviation reduction computed for the eight seasonal processes/regions to obtain the final error estimate shown in Table 3. The seasonal processes, in contrast, have been solved as monthly fluxes which already add greater uncertainty to their five-year averages.

The inversion results indicate large $\mathrm{CH}_{3} \mathrm{Cl}$ emissions of $2197 \pm 394 \mathrm{Gg} \mathrm{yr}^{-1}$ from tropical plants in the best estimate (Case 1 in Table 3), which account for $54 \pm 10 \%$ of the total emissions. The second largest emissions originate from biomass burning accounting for $22 \pm 5 \%$. The 
Table 4. Reference and optimally estimated five-year averaged surface fluxes and errors for emissions from tropical plants and biomass burning in Table 3.

\begin{tabular}{|c|c|c|c|c|c|c|c|c|c|}
\hline Flux type & Reference & $\begin{array}{l}\text { (1) In situ + NOAA } \\
\text { \& NIES flask }{ }^{1}\end{array}$ & $\begin{array}{l}\text { (2) Case (1) without } \\
\text { in situ } \mathrm{SPO}^{2}\end{array}$ & (3) $\mathrm{In} \mathrm{situ}^{3}$ & $\begin{array}{c}\text { (4) In situ without } \\
\mathrm{SPO}^{4}\end{array}$ & (5) Only AGAGE 5 & $\begin{array}{l}\text { (6) Only NOAA } \\
\text { flask }^{6}\end{array}$ & $\begin{array}{c}\text { (7) In situ without } \\
\text { NIES }^{7}\end{array}$ & $\begin{array}{l}\text { (8) In situ without } \\
\text { SOGE }^{8}\end{array}$ \\
\hline Trop AM & $862 \pm 259$ & $918 \pm 207$ & $912 \pm 208$ & $867 \pm 211$ & $860 \pm 212$ & $891 \pm 239$ & $1000 \pm 221$ & $868 \pm 211$ & $868 \pm 211$ \\
\hline Trop AS & $686 \pm 346$ & $698 \pm 256$ & $716 \pm 257$ & $673 \pm 260$ & $704 \pm 260$ & $688 \pm 284$ & $753 \pm 262$ & $672 \pm 260$ & $671 \pm 260$ \\
\hline Trop AF & $541 \pm 273$ & $580 \pm 215$ & $583 \pm 216$ & $552 \pm 217$ & $558 \pm 218$ & $551 \pm 227$ & $607 \pm 218$ & $553 \pm 217$ & $549 \pm 217$ \\
\hline BB East & $743 \pm 227$ & $727 \pm 184$ & $751 \pm 184$ & $753 \pm 190$ & $791 \pm 191$ & $729 \pm 210$ & $723 \pm 187$ & $751 \pm 191$ & $745 \pm 192$ \\
\hline BB West & $175 \pm 97$ & $190 \pm 75$ & $188 \pm 75$ & $186 \pm 79$ & $183 \pm 80$ & $181 \pm 81$ & $198 \pm 73$ & $186 \pm 79$ & $185 \pm 80$ \\
\hline
\end{tabular}

${ }^{1}$ Using data from all in situ sites, the NIES HAT flask site, and the PSA, KUM, ALT, LEF, and HFM NOAA flask sites. This is the "best estimate" inversion case shown in the figures.

2 Inversion case (1) with NOAA in situ SPO site excluded.

3 Using data from all in situ sites listed in Table 1.

${ }^{4}$ Inversion case (3) with NOAA in situ SPO site excluded.

5 Using data only from AGAGE sites MHD, THD, RPB and CGO (the SMO measurements began after the time period of 2000-2005 addressed here).

${ }^{6}$ Using data from all 13 NOAA flask sites listed in Table 1.

${ }^{7}$ Inversion case (3) with NIES data excluded.

8 Inversion case (3) with SOGE data excluded.

other source strengths are relatively small, and their percentages are $11 \pm 2 \%$ for the oceans, $4 \pm 3 \%$ for the fungi, $4 \pm 2 \%$ for the salt marshes, $4 \%$ for the industry/incineration, and $1 \%$ for the wetlands. The total global emissions are $4089 \pm 471 \mathrm{Gg} \mathrm{yr}^{-1}$ in the best estimate (Case 1 in Table 3 ). Relative to their a priori magnitudes, the inversion increases global fungal emissions, increases emissions from tropical plants and the western biomass burning source, and slightly reduces the global oceanic source and the eastern biomass burning source. The optimized global salt marsh emissions and soil sink show little change from their a priori values.

We also tested the sensitivity of the inversion results to 7 other alternative combinations of the observations used in the Kalman filter (Table 3). In general the inversion results in the 7 alternative cases studied agree within their errors with the results from the best estimate (Case 1), in part because of the consistency of the measurements from the different networks when placed on a common calibration scale.

The forward model has been run with the final optimal emission estimates, and the predicted mole fractions have been compared with the measurements. Figure 12 shows the residuals between the optimized and observed monthly mean mole fractions, compared to the residuals between the reference and observed monthly mean mole fractions at each observing site. The optimization lowers the residuals at many but not all of the sites. These differences are caused by a combination of the sensitivity of each site to the emitting regions and the precision and frequency of the measurements at the site. The average root-mean-square difference between the observed mole fractions and those calculated in the model run using the reference emissions is $31 \mathrm{ppt}$ and this difference is lowered to $24 \mathrm{ppt}$ using the model run with optimized emissions.

\section{Summary and discussion}

In this paper we solved for monthly, annual, and interannual surface fluxes for the various source and sink categories of atmospheric methyl chloride during 2000-2004 using measurements from the AGAGE, NOAA/ESRL, SOGE, and NIES sampling networks, the MATCH 3-D global chemical transport model, and a Kalman filter with monthly pulses. The state vector in the Kalman filter includes scaling factors which multiply maps of the a priori estimates of each source and sink at monthly time resolution. The final optimally estimated sources and sink were used as input for a forward run of the MATCH model to test the inversion results.

Large $\mathrm{CH}_{3} \mathrm{Cl}$ emissions of $2200 \pm 390 \mathrm{Gg} \mathrm{yr}^{-1}$ are estimated for tropical plants, which confirms the suggestion of Yokouchi et al. (2002) that tropical plants are the largest global source of $\mathrm{CH}_{3} \mathrm{Cl}$. Relative to the a priori estimates, the inversion estimates indicate increases in global fungal and tropical plant emissions, and reductions in global ocean emissions. Our revised budget indicates that a substantial fraction of the $\mathrm{CH}_{3} \mathrm{Cl}$ sources reside in the tropics and subtropics (Fig. 13). Of our 20 independent observing sites, only 5 are tropical or sub-tropical (Barbados, Samoa, Hateruma, Mauna Loa, Mauna Kea), which implies the need for more tropical (preferably in situ) continuous observing sites in order to improve our understanding of the magnitudes and variabilities of the dominant tropical sources. Future inversions could also utilize short-term aircraft campaign data (e.g., Blake et al., 1996).

Regarding the temporal variability of the deduced fluxes, the inversion generally implies greater seasonal oscillations of the natural sources and sink of $\mathrm{CH}_{3} \mathrm{Cl}$ compared to the a priori estimates. The inversion also reflects strong effects of the 2002/2003 globally wide-spread warm episodes and droughts on the global soil sink and on the emissions from tropical plants, biomass burning, and global salt marshes. While the 2002/2003 El Niño was moderate compared to the 

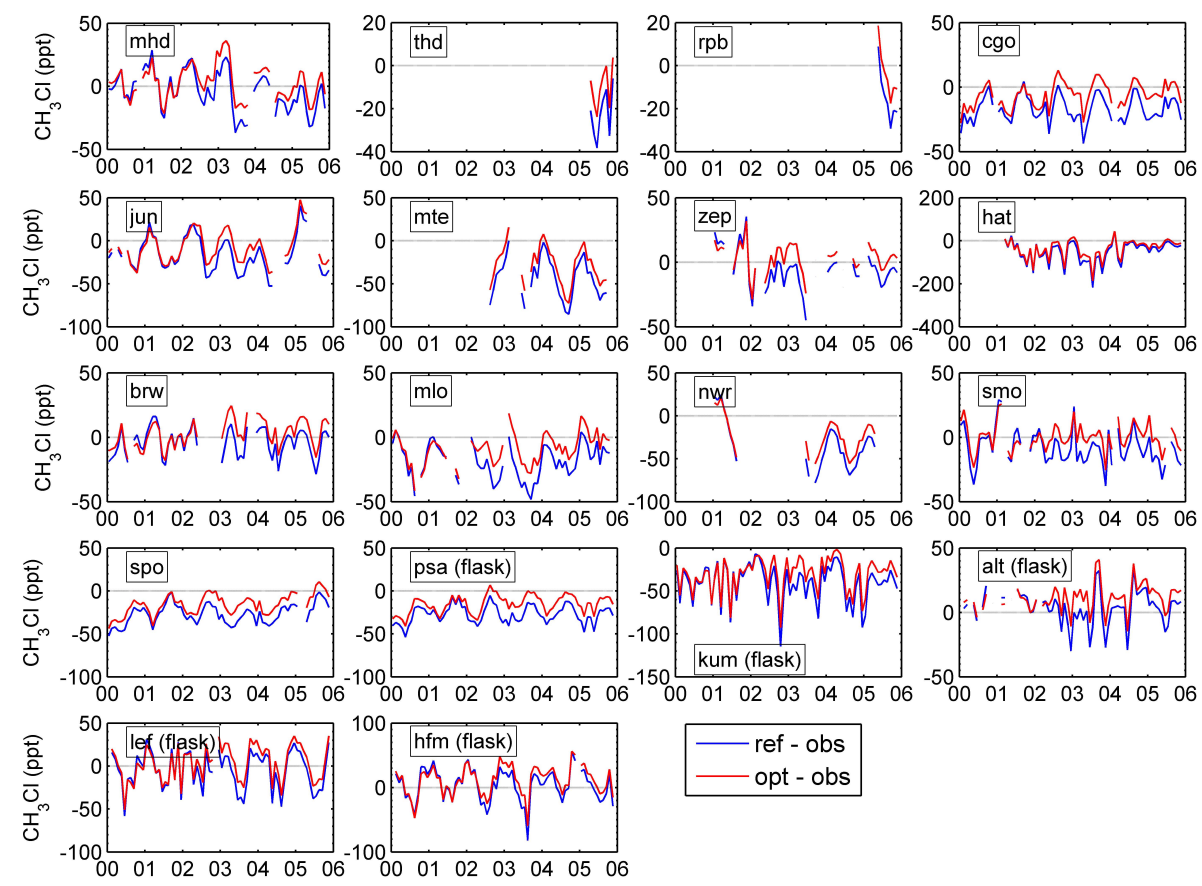

Fig. 12. Residuals between the optimized and observed monthly mean mole fractions of $\mathrm{CH}_{3} \mathrm{Cl}$ (red lines), compared to the residuals between the reference and observed monthly mean mole fractions (blue lines) at each observing site.

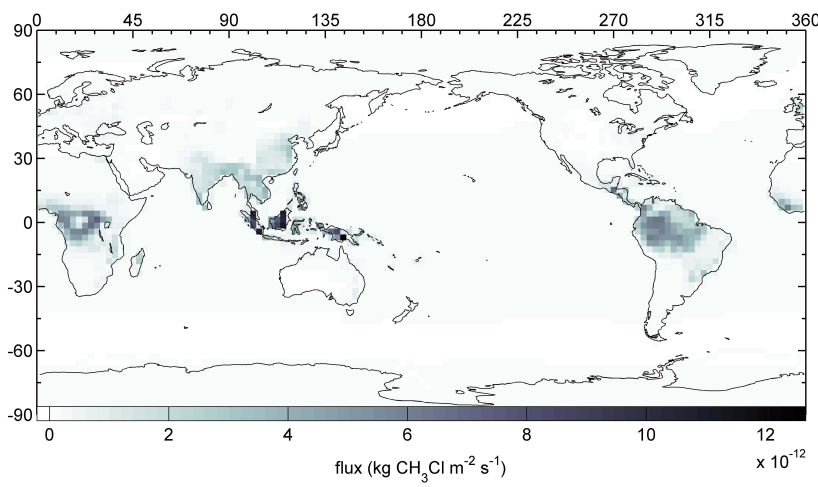

Fig. 13. A posteriori annual average distribution of combined $\mathrm{CH}_{3} \mathrm{Cl}$ surface fluxes from the estimated sources and sink, the constant industrial source, and the annual average wetland emissions.

1997/1998 El Niño, the global land precipitation appeared unusually low during this time period. There is evidence that the unusually dry land conditions have led to a strong NPP decrease, which can be expected to have caused a decrease in emissions of $\mathrm{CH}_{3} \mathrm{Cl}$ from tropical plants. The anomalously dry and hot climate may also have led to increased insect damage to vegetation and they have increased the susceptibility of the biomass to large-scale burning, leading to an increase in global biomass burning emissions of $\mathrm{CH}_{3} \mathrm{Cl}$. Furthermore, decreased organic matter content and microbial activity in soils associated with the dry conditions may be the reason for a reduction in global in-soil consumption. Possi- ble future climate change involving increasingly dry and hot summers may lead to increased occurrence of reductions in emissions from the tropical biosphere and in uptake by soils, and increases in emissions from salt marshes and biomass burning. Therefore future $\mathrm{CH}_{3} \mathrm{Cl}$ levels will probably be dependent on climate change and will contribute to the future trend in stratospheric chlorine. Future studies involving coupled climate change/climate dependent $\mathrm{CH}_{3} \mathrm{Cl}$ emissions may be necessary to more precisely predict global ozone recovery over the next 50 years.

Our inversions for the interannual variability of different source or sink categories of $\mathrm{CH}_{3} \mathrm{Cl}$ are unavoidably affected by the uncertainties in other model parameters which were not included in the inversions. We have used interannually varying meteorological data from observed meteorological reanalyses to minimize the uncertainty caused by transport, because interannual variations of transport can strongly affect calculated mole fractions (Chen and Prinn, 2005). Another uncertainty originates from interannual variability of $\mathrm{OH}$ concentrations. In the inversions we used annually repeating $\mathrm{OH}$ fields. A change of a few percent in the global average OH concentrations in the period 2000-2004 would cause an uncertainty of the same magnitude in the total deduced sources which is well within the errors of our emission estimates.

Our results depend on the veracity of the assumed patterns of emissions from the processes and regions included in the inversions. These patterns were based on significant prior knowledge and there is currently no reasonable basis 
to justify alternative distributions. Note also that we use monthly average measurements that omit obvious large pollution events in our inversions. Hence, our aggregate regional emissions are not biased by errors in the distribution of emissions at grid points close enough to the observing stations to produce these pollution events.

Finally, although the inverse modeling approach can be used to quantitatively estimate the magnitudes of sources and sinks of $\mathrm{CH}_{3} \mathrm{Cl}$, field and laboratory experiments are still necessary to improve the understanding of the mechanisms for the biochemical processes that control its natural sources and sinks. Keppler et al. (2005) studied the abiotic methylation of chloride in terrestrial ecosystems, and calculated a global soil sink for $\mathrm{CH}_{3} \mathrm{Cl}$ of more than $1000 \mathrm{Gg} \mathrm{yr}^{-1}$, which is much larger than our estimate thus inviting further process studies of this sink.

\section{Appendix A}

\section{The Kalman filter}

The Kalman filter has been used in a number of studies to estimate the atmospheric lifetime or global sources of chlorofluorocarbons (e.g., Cunnold et al., 1983; Hartley and Prinn, 1993; Mahowald et al, 1997b; Mulquiney and Norton, 1998; Prinn et al., 2000) and other trace gases (e.g., Xiao et al., 2007, 2010; Xiao, 2008). It processes all available measurements, accounting for their precision, to estimate the current values of the quantities of interest (the states), with use of: (1) knowledge of the system and measurement instrument dynamics; (2) the statistical description of the system errors, measurement noise, and uncertainty in the dynamics models; and (3) any available information about the initial conditions of the state variables of interest. The covariance matrix, $\mathbf{P}$, of the error in the state estimate is also computed.

An introduction to the Kalman filter for application to estimating sources and sinks for atmospheric trace gases can be found in Prinn (2000), in which the Kalman filter recursion from time $k-1$ to time $k$ consists of two steps:

Step 1: state vector extrapolation

$$
\begin{aligned}
\boldsymbol{x}_{k}^{\mathrm{f}} & =\mathbf{M}_{k-1} \boldsymbol{x}_{k-1}^{\mathrm{a}} \\
\mathbf{P}_{k}^{\mathrm{f}} & =\mathbf{M}_{k-1} \mathbf{P}_{k-1}^{\mathrm{a}} \mathbf{M}_{k-1}^{\mathrm{T}}+\mathbf{Q}_{k-1}
\end{aligned}
$$

Step 2: state vector improvement

$$
\begin{aligned}
& \boldsymbol{x}_{k}^{\mathrm{a}}=\boldsymbol{x}_{k}^{\mathrm{f}}+\mathbf{K}_{k}\left(\boldsymbol{y}_{k}^{\mathrm{o}}-\mathbf{H}_{k} \boldsymbol{x}_{k}^{\mathrm{f}}\right) \\
& \mathbf{P}_{k}^{\mathrm{a}}=\mathbf{P}_{k}^{\mathrm{f}}-\mathbf{K}_{k} \mathbf{H}_{k} \mathbf{P}_{k}^{\mathrm{f}}
\end{aligned}
$$

where

$$
\mathbf{K}_{k}=\mathbf{P}_{k}^{\mathrm{f}} \mathbf{H}_{k}^{\mathrm{T}}\left(\mathbf{H}_{k} \mathbf{P}_{k}^{\mathrm{f}} \mathbf{H}_{k}^{\mathrm{T}}+\mathbf{R}_{k}\right)^{-1}
$$

is the Kalman gain matrix. In the equations $\boldsymbol{x}_{k}$ is the state vector (the superscripts $f$ and a refer to the values before (forecast) and after (analysis) the use of the $k$-th measurement $\left.\boldsymbol{y}_{k}^{\mathrm{o}}\right) . \quad \mathbf{R}_{k}$ is the associated measurement error covariance matrix, and $\mathbf{H}_{k}$ is the sensitivity matrix that relates mole fraction changes at observation sites to emission changes at different regions. The matrices $\mathbf{Q}$ and $\mathbf{M}$ are discussed later.

Here we use the unit pulse method of Chen and Prinn (2006), in which we adapt the Kalman filter to estimate $\mathrm{CH}_{3} \mathrm{Cl}$ surface fluxes from different sources and sinks at monthly time resolution on regional or global scales. Suppose we have $n_{\text {as }}$ time invariant (aseasonal) and $n_{\mathrm{s}}$ seasonally varying surface flux variables for $N$ years. The full state vector is therefore composed of $n_{\text {as }}+N \times 12 \times n_{\mathrm{s}}$ elements. This is a large number and imposes a large demand on computer time. However, because the global horizontal mixing time in the model is about 1 year, an observation cannot meaningfully provide information about monthly fluxes that occur more than one year before the observation (Chen and Prinn, 2006). Hence, it is a good approximation to use a specific monthly observation at time $k$ to deduce not all but only those monthly fluxes from time $k$ back to time $k-T$ (where $T=11$ months). The resultant down-sized state vector was given earlier in Eq. (1):

$\boldsymbol{x}_{k}=\left[\begin{array}{l}\boldsymbol{X}_{k}^{\mathrm{as}} \\ \boldsymbol{X}_{k}^{\mathrm{s}} \\ \boldsymbol{X}_{k-1}^{\mathrm{s}} \\ \cdots \\ \boldsymbol{X}_{k-T}^{\mathrm{s}}\end{array}\right]$

where $\boldsymbol{X}_{k}^{\text {as }}$ is a subvector containing all the $n_{\text {as }}$ aseasonal flux variables, and $\boldsymbol{X}_{k}^{\mathrm{s}}$ is a subvector containing all the $n_{\mathrm{s}}$ monthly/seasonal flux variables at time $k$. Notice that $\boldsymbol{X}_{k-T}^{\mathrm{s}}$ contains the "oldest" seasonal fluxes that the observation $\boldsymbol{y}_{k}^{\mathrm{o}}$ can provide meaningful information about. Therefore it contains the final, optimized solution for fluxes at time $k-T$ and is then removed from the state vector before a new observation $\boldsymbol{y}_{k+1}^{\mathrm{o}}$ is included. To achieve this removal, Chen and Prinn (2006) borrow the mathematics (but not the underlying concepts) used for extrapolation of the state vector and its error covariance matrix (Eqs. A1 and A2). A constant transition matrix is used with the following form:

$\mathbf{M}=\left[\begin{array}{ccccc}\mathbf{I}_{n_{\mathrm{as}}} & 0 & 0 & 0 & 0 \\ 0 & 0 & 0 & 0 & 0 \\ 0 & \mathbf{I}_{n_{\mathrm{s}}} & 0 & 0 & 0 \\ 0 & 0 & \mathbf{I}_{n_{\mathrm{s}}} & 0 & 0 \\ \ldots & \ldots & \ldots & \ldots & \ldots \\ 0 & 0 & 0 & \mathbf{I}_{n_{\mathrm{s}}} & 0\end{array}\right]$

where $\mathbf{I}_{n_{\mathrm{as}}}$ and $\mathbf{I}_{n_{\mathrm{s}}}$ represent square identity sub-matrices of sizes $n_{\text {as }}$ and $n_{\mathrm{S}}$ corresponding to $n_{\text {as }}$ aseasonal fluxes and $n_{\mathrm{s}}$ seasonal fluxes, respectively. The 0 's represent matrices with 
all zero elements. The transition matrix operates on the state vector as follows:

$$
\begin{aligned}
& {\left[\begin{array}{ccccc}
\mathbf{I}_{n_{\mathrm{as}}} & 0 & 0 & 0 & 0 \\
0 & 0 & 0 & 0 & 0 \\
0 & \mathbf{I}_{n_{\mathrm{s}}} & 0 & 0 & 0 \\
0 & 0 & \mathbf{I}_{n_{\mathrm{s}}} & 0 & 0 \\
\cdots & \cdots & \cdots & \cdots & \cdots \\
0 & 0 & 0 & \mathbf{I}_{n_{s}} & 0
\end{array}\right] \cdot\left[\begin{array}{c}
\boldsymbol{X}_{k}^{\mathrm{as}} \\
\boldsymbol{X}_{k}^{\mathrm{s}} \\
\boldsymbol{X}_{k-1}^{\mathrm{s}} \\
\cdots \\
\boldsymbol{X}_{k-T+1}^{\mathrm{s}} \\
\boldsymbol{X}_{k-T}^{\mathrm{s}}
\end{array}\right] \longrightarrow \longrightarrow \longrightarrow\left[\begin{array}{c}
\boldsymbol{X}_{k}^{\mathrm{as}} \\
0 \\
\boldsymbol{X}_{k}^{\mathrm{s}} \\
\boldsymbol{X}_{k-1}^{\mathrm{s}} \\
\cdots \\
\boldsymbol{X}_{k-T+1}^{\mathrm{s}}
\end{array}\right]} \\
& \boldsymbol{X}_{k-T}^{\mathrm{s}}=\text { optimized fluxes }
\end{aligned}
$$

Multiplying $\boldsymbol{x}_{k}$ by $\mathbf{M}$ not only removes $\boldsymbol{X}_{k-T}^{\mathrm{s}}$ which is saved as the final, optimized solution, but also introduces a new $\boldsymbol{X}_{k+1}^{\mathrm{s}}$ whose initial guess is its (unity) a priori value. For the aseasonal components, the transition matrix retains the previous values, which is consistent with the estimation of time invariant fluxes over all time steps.

Operation of $\mathbf{M}$ on the error covariance matrix $\mathbf{P}_{k}^{\mathrm{a}}$ of $\boldsymbol{x}_{k}$ has similar effects as on $\boldsymbol{x}_{k}$ by removing the error covariances of $\boldsymbol{X}_{k-T}^{\mathrm{s}}$, but it introduces zeros for the initial error covariances of $\boldsymbol{X}_{k+1}^{\mathrm{s}}$ to be estimated. This problem is solved by including the matrix $\mathbf{Q}_{k}$ in the following form:

$\mathbf{Q}_{k}=\left[\begin{array}{ccccc}0 & 0 & 0 & 0 & 0 \\ 0 & \mathrm{E}\left[\boldsymbol{e}_{k} \boldsymbol{e}_{k}^{\mathrm{T}}\right] & 0 & 0 & 0 \\ 0 & 0 & 0 & 0 & 0 \\ 0 & 0 & 0 & 0 & 0 \\ \ldots & \ldots & \ldots & \ldots & \ldots \\ 0 & 0 & 0 & 0 & 0\end{array}\right]$

where $\mathrm{E}\left[\boldsymbol{e}_{k} \boldsymbol{e}_{k}^{\mathrm{T}}\right]$ represents the choice of the initial error covariances associated with the new seasonal flux adjustments $\left(\boldsymbol{X}_{k+1}^{\mathrm{s}}\right)$.

Acknowledgements. We thank David Kicklighter and Julia LeeTaylor for sharing their research results as the a priori inputs into this work. We also thank the two anonymous reviewers for their constructive comments that improved the manuscript. The inversions and the AGAGE measurements were supported by a variety of sources, including: NASA grants NNX07AE89G, NAG5-12669 and NAG5-12099 (and associated NCCS computer support), and NSF grant ATM-0120468 (and associated NCAR computer support) to MIT; NASA grants NNX07AF09G and NNX07AE87G, to SIO; the Australian Bureau of Meteorology and CSIRO-MAR; and DEFRA grants EPG 1/1/159, CPEG 24, and GA01081 to Bristol University. The HATS flask and HATS high frequency in situ measurements were supported by NOAA-ESRL. Financial support for the Zeppelin measurements is acknowledged from the Norwegian Pollution Control Authority (SFT). NIES measurements were supported by the Global Environment Research Fund (Ministry of the Environment of Japan).

Edited by: P. Monks

\section{References}

Ayres, M. P. and Lombardero, M. J.: Assessing the consequences of global change for forest disturbance from herbivores and pathogens, Sci. Total Environ., 262, 263-286, 2000.

Balzter, H., Gerard, F. F., George, C. T., Rowland, C. S., Jupp, T. E., McCallum, I., Shvidenko, A., Nilsson, S., Sukhinin, A., Onuchin, A., and Schmullius, C.: Impact of the Arctic oscillation pattern on interannual forest fire variability in Central Siberia, Geophys. Res. Lett., 32, L14709, doi:10.1029/2005GL022526, 2005.

Blake, N. J., Blake, D. R., Sive, B. C., Chen, T.-Y., Rowland, F. S., Collins Jr., J. E., Sachse, G. W., and Anderson, B. E.: Biomass burning emissions and vertical distribution of atmospheric methyl halides and other reduced carbon gases in the South Atlantic region, J. Geophys. Res., 101, D19, 24151-24164, 1996.

Butler, J. H., Battle, M., Bender, M., Montzka, S. A., Clarke, A. D., Saltzman, E. S., Sucher, C., Severinghaus, J., and Elkins, J. W.: A twentieth century record of atmospheric halocarbons in polar firn air, Nature, 399, 749-755, 1999.

Chen, Y.-H. and Prinn, R. G.: Atmospheric modeling of highand low-frequency methane observations: Importance of interannually varying transport, J. Geophys. Res., 110, D10303, doi:10.1029/2004JD005542, 2005.

Chen, Y.-H. and Prinn, R. G.: Estimation of atmospheric methane emissions between 1996 and 2001 using a three-dimensional global chemical transport model, J. Geophys. Res., 111, D10307, doi:10.1029/2005JD006058, 2006.

Ciais, P., Reichstein, M., Viovy, N., Granier, A., Ogée, J., Allard, V., Aubinet, M., Buchmann, N., Bernhofer, C., Carrara, A., Chevallier, F., Noblet, N. D., Friend, A. D., Friedlingstein, P., Grünwald, T., Heinesch, B., Keronen, P., Knohl, A., Krinner, G., Loustau, D., Manca, G., Matteucci, G., Miglietta, F., Ourcival, J. M., Papale, D., Pilegaard, K., Rambal, S., Seufert, G., Soussana, J. F., Sanz, M. J., Schulze, E. D., Vesala, T., and Valentini, R.: Europewide reduction in primary productivity caused by the heat and drought in 2003, Nature, 437, 529-533, 2005.

Clerbaux, C. and Cunnold, D. M.: Chapter 1 in: Scientific Assessment of Ozone Depletion: 2006, Global Ozone Research and Monitoring Project Report No. 50, Geneva, Nairobi; Washington, DC, Brussells: NOAA, NASA, UNEP, WMO, EC., 1.11.63, 2006.

Cleveland, C. C., Holland, E. A., and Neff, J. C.: Temperature regulation of soil respiration in an alpine tundra ecosystem, paper presented at the Front Range Branch Annual Meeting, Am. Geophys. Union, Golden, Colo., 8-10 February, 1993.

Cox, M. L., Sturrock, G. A., Fraser, P. J., Siems, S. T., Krummel, P. B., and O'Doherty, S.: Regional sources of methyl chloride, chloroform and dichloromethane identified from AGAGE observations at Cape Grim, Tasmania, 1998-2000, J. Atmos. Chem., 45, 79-99, 2003.

Cox, M. L., Fraser, P. J., Sturrock, G. A., Siems, S. T., and Porter, L. W.: Terrestrial sources and sinks of halomethanes near Cape Grim, Tasmania, Atmos. Environ., 38(23), 3839-3852, 2004.

Cunnold, D. M., Prinn, R. G., Rasmussen, R. A., Simmonds, P. G., Alyea, F. N., Cardelino, C. A., Crawford, A. J., Fraser, P. J., and Rosen, R. D.: The Atmospheric Lifetime Experiment 3. Lifetime methodology and application to three years of $\mathrm{CFCl}_{3}$ Data, J. Geophys. Res., 88(C13), 8379-8400, 1983. 
Graedel, T. E. and Keene, W. C.: The tropospheric budget of reactive chlorine, Global Biogeochem. Cy., 9, 47-77, 1995.

Graedel, T. E. and Keene, W. C.: The budget and cycle of Earth's natural chlorine, Pure Appl. Chem., 68, 1687-1689, 1996.

Graedel, T. E. and Keene, W. C.: Preface, J. Geophys. Res., 104(D7), 8331-8332, 1999.

Guenther, A., C. Hewitt, N., Erickson, D., Fall, R., Geron, C., Graedel, T., Harley, P., Klinger, L., Lerdau, M., McKay, W. A., Pierce, T., Scholes, B., Steinbrecher, R., Tallamraju, R., Taylor, J., and Zimmerman, P.: A global model of natural volatile organic compound emissions, J. Geophys. Res., 100(D5), 8873$8892,1995$.

Hamilton, J. T. G., McRoberts, W. C., Keppler, F., Kalin, R. M., and Harper, D. B.: Chloride methylation by plant pectin: An efficient environmentally significant process, Science, 301, 206209, 2003.

Hao, W. M. and Liu, M.-H.: Spatial and temporal distribution of tropical biomass burning, Global Biogeochem. Cy., 8(4), 495503, 1994.

Hartley, D. E. and Prinn, R. G.: On the feasibility of determining surface emissions of trace gases using an inverse method in a three-dimensional chemical transport model, J. Geophys. Res., 98, 5183-5198, 1993.

Holland, E. A., Townsend, A. R., and Vitousek, P. M.: Variability in temperature regulation of $\mathrm{CO}_{2}$ fluxes and $\mathrm{N}$ mineralization from five Hawaiian soils: Implications for a changing climate, Global Change Biol., 1, 115-123, 1995.

Jöckel, P.: Cosmogenic ${ }^{14} \mathrm{CO}$ as tracer for atmospheric chemistry and transport, Rpertus Carola University of Heidelberg, Heidelberg, 2000.

Keene, W. C., Khalil, M. A. K., Erickson III, D. J., McCulloch, A., Graedel, T. E., Lobert, J. M., Aucott, M. L., Gong, S. L., Harper, D. B., Kleiman, G., Midgley, P., Moore, R. M., Seuzaret, C., Sturges, W. T., Benkovitz, C. M., Koropalov, V., Barrie, L. A., and Li, Y. F.: Composite global emissions of reactive chlorine from anthropogenic and natural sources: Reactive Chlorine Emissions Inventory, J. Geophys. Res., 104(D7), 8429-8440, 1999.

Keppler, F., Harper, D. B., Röckmann, T., Moore, R. M., and Hamilton, J. T. G.: New insight into the atmospheric chloromethane budget gained using stable carbon isotope ratios, Atmos. Chem. Phys., 5, 2403-2411, doi:10.5194/acp-5-2403-2005, 2005.

Khalil, M. A. K.: Reactive chlorine compounds in the atmosphere, in: Reactive Halogen Compounds in the Atmosphere, edited by: Fabian, P. and Singh, O. N., Springer-Verlag, Berlin, Heidelburg New York, 45-79, 1999.

Khalil, M. A. K. and Rasmussen, R. A.: Atmospheric methyl chloride, Atmos. Environ., 33, 1305-1321, 1999.

Khalil, M. A. K., Moore, R. M., Harper, D. B., Lobert, J. M., Erickson, D. J., Koropalov, V., Sturges, W. T., and Keene, W. C.: Natural emissions of chlorine-containing gases: Reactive Chlorine Emission Inventory, J. Geophys. Res., 104(D7), 8333-8346, 1999.

Knorr, W., Gobron, N., Scholze, M., Kaminski, T., Schnur, R., and Pinty, B.: Impact of terrestrial biosphere carbon exchanges on the anomalous $\mathrm{CO}_{2}$ increase in 2002-2003, Geophys. Res. Lett., 34, L09703, doi:10.1029/2006GL029019, 2007.

Kobak, K. I., Turchinovich, I. Y., Kondrasheva, N. Y., Schulze, E. D., Schulze, W., Koch, H., and Vygodskaya, N. N.: Vulnerability and adaptation of the larch forest in eastern Siberia to climate change, Water Air Soil Pollut., 92, 119-127, 1996.

Krummel, P. B.: the AGAGE team and respective participating laboratory investigators: Inter-comparison of AGAGE trace gases with other laboratories: ftp://gaspublic:gaspublic@ftp.dar.csiro. au/agage/, last access: 27 January 2009.

Lawrence, M. G., Crutzen, P. J., Rasch, P. J., Eaton, B. E., and Mahowald, N. M.: A model for studies of tropospheric photochemistry: Description, global distributions, and evaluation, J. Geophys. Res., 104(D21), 26245-26277, 1999.

Lee-Taylor, J. M., Doney, S. C., Brasseur, G. P., and Müller, J.-F.: A global three-dimensional atmosphere-ocean model of methyl bromide distributions, J. Geophys. Res., 103(D13), 1603916057, 1998.

Lee-Taylor, J. M., Brasseur, G. P., and Yokouchi, Y.: A preliminary three-dimensional global model study of atmospheric methyl chloride distributions, J. Geophys. Res., 106(D24), 3422134233, 2001

Lobert, J. M., Keene, W. C., Logan, J. A., and Yevich, R.: Global chlorine emissions from biomass burning: Reactive Chlorine Emissions Inventory, J. Geophys. Res., 104(D7), 8373-8389, 1999.

Lucas, D. D. and Prinn, R. G.: Sensitivities of gas-phase dimethylsulfide oxidation products to the assumed mechanisms in a chemical transport model, J. Geophys. Res., 110, D21312, doi:10.1029/2004JD005386, 2005.

Lyon, B: The strength of El Niño and the spatial extent of tropical drought, Geophys. Res. Lett., 31, L21204, doi:10.1029/2004GL020901, 2004.

Mahowald, N. M.: Development of a 3-dimensional chemical transport model based on observed winds and use in inverse modeling of the source of $\mathrm{CCl}_{3} \mathrm{~F}, \mathrm{PhD}$ thesis, MIT, Cambridge, 1996.

Mahowald, N. M., Rasch, P. J., Eaton, B. E., Whittlestone, S., and Prinn, R. G.: Transport of ${ }^{222}$ radon to the remote troposphere using the Model of Atmospheric Transport and Chemistry and assimilated winds from ECMWF and the National Center for Environmental Prediction/NCAR, J. Geophys. Res., 102(D23), 28139-28151, 1997a.

Mahowald, N. M., Prinn, R. G., and Rasch, P. J.: Deducing $\mathrm{CCl}_{3} \mathrm{~F}$ emissions using an inverse method and chemical transport models with assimilated winds, J. Geophys. Res., 102(D23), 28153 28168, 1997b.

McCulloch, A., Aucott, M. L., Benkovitz, C. M., Graedel, T. E., Kleiman, G., Midgley, P. M., and Li, Y. F.: Global emissions of hydrogen chloride and chloromethane from coal combustion, incineration and industrial activities: Reactive Chlorine Emissions Inventory, J. Geophys. Res., 104(D7), 8391-8403, 1999.

McGuire, A. D., Sitch, S., Clein, J. S., Dargaville, R., Esser, G., Foley, J., Heimann, M., Joos, F., Kaplan, J., Kicklighter, D. W., Meier, R. A., Melillo, J. M., Moore III, B., Prentice, I. C., Ramankutty, N., Reichenau, T., Schloss, A., Tian, H., Williams, L. J., and Wittenberg, U.: Carbon balance of the terrestrial biosphere in the twentieth century: analyses of $\mathrm{CO}_{2}$, climate and land use effects with four process-based ecosystem models, Global Biogeochem. Cy., 15(1), 183-206, 2001.

Montzka, S. A., Butler, J. H., Elkins, J. W., Thompson, T. M., Clarke, A. D., and Lock, L. T.: Present and future trends in the atmospheric burden of ozone-depleting halogens, Nature, 398, 690-694, 1999. 
Montzka, S. A., Spivakovsky, C. M., Butler, J. H., Elkins, J. W., Lock, L. T., and Mondeel, D. J.: New observational constraints for atmospheric hydroxyl on global and hemispheric scales, Science, 288, 500-503, 2000.

Montzka, S. A. and Fraser, P. J.: Controlled substances and other gas sources, Chapter 1 in: Scientific Assessment of Ozone Depletion: 2002, Global Ozone Research and Monitoring Project Report No. 47, Geneva, Nairobi; Washington, D.C., Brussells: WMO, UNEP, NOAA, NASA, EC., 1.1-1.83, 2003.

Moore, R. M., Groszko, W., and Niven, S. J.: Ocean-atmosphere exchange of methyl chloride: Results from NW Atlantic and Pacific Ocean studies, J. Geophys. Res., 101(C12), 28529-28538, 1996.

Moore, R. M., Gut, A., and Andreae, M. O.: A pilot study of methyl chloride emissions from tropical woodrot fungi, Chemosphere, 58(2), 221-225, 2005.

Mulquiney, J. E. and Norton, J. P.: A new inverse method for trace gas flux estimation 1. State-space model identification and constraints, J. Geophys. Res., 103(D1), 1417-1427, 1998.

Prinn, R. G.: Measurement equation for trace chemicals in fluids and solution of its inverse, in: Inverse Methods in Global Biogeochemical Cycles, edited by: Kasibhatla, P., Heimann, M., Rayner, P., et al., Geophys. Monogr. Ser., 114, 3-18, AGU, Washington, DC, 2000.

Prinn, R. G., Weiss, R. F., Fraser, P. J., Simmonds, P. G., Cunnold, D. M., Alyea, F. N., O'Doherty, S., Salameh, P., Miller, B. R., Huang, J., Wang, R. H. J., Hartley, D. E., Harth, C., Steele, L. P., Sturrock, G., Midgley, P. M., and McCulloch, A.: A history of chemically and radiatively important gases in air deduced from ALE/GAGE/AGAGE, J. Geophys. Res., 105(D14), 1775117792, 2000.

Prinn, R. G., Huang, J., Weiss, R. F., Cunnold, D. M., Fraser, P. J., Simmonds, P. G., McCulloch, A., Harth, C., Salameh, P., O'Doherty, S., Wang, R. H. J., Porter, L., and Miller, B. R.: Evidence for variability of atmospheric hydroxyl radicals over the past quarter century, Geophys. Res. Lett., 32, L07809, doi:10.1029/2004GL022228, 2005.

Rasch, P. J., Mahowald, N. M., and Eaton, B. E.: Representations of transport, convection, and the hydrologic cycle in chemical transport models: Implications for the modeling of short-lived and soluble species, J. Geophys. Res., 102(D23), 28127-28138, 1997.

Rhew, R. C., Miller, B. R., and Weiss, R. F.: Natural methyl bromide and methyl chloride emissions from coastal salt marshes, Nature, 403, 292-295, 2000.

Sander, S. P., Friedl, R. R., Golden, D. M., Kurylo, M. J., Moortgat, G. K., Keller-Rudek, H., Wine, P. H., Ravishankara, A. R., Kolb, C. E., Molina, M. J., Finlayson-Pitts, B. J., Huie, R. E., and Orkin, V. L.: Chemical Kinetics and Photochemical Data for Use in Atmospheric Studies, Evaluation No. 15, JPL Publication 06-2, Jet Propulsion Laboratory, Pasadena, Calif, 2006.

Schär, C., Vidale, P. L., Lüthi, D., Frei, C., Häberli, C., Liniger, M. A., and Appenzeller, C.: The role of increasing temperature variability in European summer heatwaves, Nature, 427, 332336, 2004.

Seinfeld, J. H. and Pandis, S. N.: Atmospheric chemistry and physics: from air pollution to climate change, A WileyInterscience publication, USA, 1326 pp., 1998.
Shorter, J. H., Kolb, C. E., Crill, P. M., Kerwin, R. A., Talbot, R. W., Hines, M. E., and Harriss, R. C.: Rapid degradation of atmospheric methyl bromide in soils, Nature, 377, 717-719, 1995.

Simmonds, P. G., Derwent, R. G., Manning, A. J., Fraser, P. J., Krummel, P. B., O’Doherty, S., Prinn, R. G., Cunnold, D. M., Miller, B. R., Wang, H. J., Ryall, D. B., Porter, L. W., Weiss, R. F., and Salameh, P. K.: AGAGE observations of methyl bromide and methyl chloride at Mace Head, Ireland, and Cape Grim, Tasmania, 1998-2001, J. Atmos. Chem., 47(3), 243-269, 2004.

Simmonds, P. G., Manning, A. J., Derwent, R. G., Ciais, P., Ramonet, M., Kazan, V., and Ryall, D.: A burning question. Can recent growth rate anomalies in the greenhouse gases be attributed to large-scale biomass burning events?, Atmos. Environ., 39, 2513-2517, 2005.

Singh, H. B.: Halogens in the atmospheric environment, in Composition, Chemistry and Climate of the Atmosphere, edited by: Singh, H. B., 216-250, Van Nostrand Reinhold, New York, 1995.

Trudinger, C. M., Etheridge, D. M., Sturrock, G. A., Fraser, P. J., Krummel, P. B., and McCulloch, A.: Atmospheric histories of halocarbons from analysis of Antarctic firn air: Methyl bromide, methyl chloride, chloroform, and dichloromethane, J. Geophys. Res., 109, D22310, doi:10.1029/2004JD004932, 2004.

Varner, R. K., Crill, P. M., and Talboat, R. W.: Wetlands: a potentially significant source of atmospheric methyl bromide and methyl chloride, Geophys. Res. Lett., 26(16), 2433-2436, 1999.

von Kuhlmann, R., Lawrence, M. G., Crutzen, P. J., and Rasch, P. J.: A model for studies of tropospheric ozone and nonmethane hydrocarbons: Model description and ozone results, J. Geophys. Res., 108(D9), 4294, doi:10.1029/2002JD002893, 2003.

Watling, R. and Harper, D. B.: Chloromethane production by woodrotting fungi and an estimate of the global flux to the atmosphere, Mycol. Res., 102, 769-787, 1998.

Xiao, X., Prinn, R. G., Simmonds, P. G., Steele, L. P., Novelli, P. C., Huang, J., Langenfelds, R. L., O’Doherty, S., Krummel, P. B., Fraser, P. J., Porter, L. W., Weiss, R. F., Salameh, P., and Wang, R. H. J.: Optimal estimation of the soil uptake rate of molecular hydrogen from the Advanced Global Atmospheric Gases Experiment and other measurements, J. Geophys. Res., 112, D07303, doi:10.1029/2006JD007241, 2007.

Xiao, X.: Optimal estimation of the surface fluxes of chloromethanes using a 3-D global atmospheric chemical transport model, PhD thesis, MIT, Cambridge, 2008.

Xiao, X., Prinn, R. G., Fraser, P. J., Weiss, R. F., Simmonds, P. G., O'Doherty, S., Miller, B. R., Salameh, P. K., Harth, C. M., Krummel, P. B., Golombek, A., Porter, L. W., Elkins, J. W., Dutton, G. S., Hall, B. D., Steele, L. P., Wang, R. H. J., and Cunnold, D. M.: Atmospheric three-dimensional inverse modeling of regional industrial emissions and global oceanic uptake of carbon tetrachloride, Atmos. Chem. Phys. Discuss., 10, 12225-12260, doi:10.5194/acpd-10-12225-2010, 2010.

Yokouchi, Y., Noijiri, Y., Barrie, L. A., Toom-Sauntry, D., Machida, T., Inuzuka, Y., Akimoto, H., Li, H. J., Fujinuma, Y., and Aoki, S.: A strong source of methyl chloride to the atmosphere from tropical coastal land, Nature, 403, 295-298, 2000.

Yokouchi, Y., Ikeda, M., Inuzuka, Y., and Yukawa, T.: Strong emission of methyl chloride from tropical plants, Nature, 416, 163165, 2002. 
Yoshida, Y., Wang, Y., Shim, C., Cunnold, D., Blake, D. R., and Dutton, G. S.: Inverse modeling of the global methyl chloride sources, J. Geophys. Res., 111, D16307, doi:10.1029/2005JD006696, 2006.
Zeng, N., Qian, H., Roedenbeck, C., and Heimann, M.: Impact of 1998-2002 midlatitude drought and warming on terrestrial ecosystem and the global carbon cycle, Geophys. Res. Lett., 32, L22709, doi:10.1029/2005GL024607, 2005. 